\title{
Summertime $\mathrm{NO}_{\mathrm{x}}$ measurements during the CHABLIS campaign: can source and sink estimates unravel observed diurnal cycles?
}

\author{
S. J.-B. Bauguitte ${ }^{1, *}$, W. J. Bloss ${ }^{2, * *}$, M. J. Evans ${ }^{3,{ }^{* * *}}$, R. A. Salmon ${ }^{1}$, P. S. Anderson ${ }^{1}$, A. E. Jones ${ }^{1}$, J. D. Lee ${ }^{2, * * *}$, \\ A. Saiz-Lopez ${ }^{4 * * *}$, H. K. Roscoe ${ }^{1}$, E. W. Wolff ${ }^{1}$, and J. M. C. Plane ${ }^{4 * * * *}$ \\ ${ }^{1}$ British Antarctic Survey, Natural Environment Research Council, High Cross, Madingley Road, Cambridge CB3 0ET, UK \\ ${ }^{2}$ School of Chemistry, University of Leeds, Leeds, LS2 9JT, UK \\ ${ }^{3}$ School of Earth and the Environment, University of Leeds, LS2 9JT, UK \\ ${ }^{4}$ School of Environmental Sciences, UEA, Norwich NR4 7TJ, UK \\ * now at: Facility for Airborne Atmospheric Measurements, Natural Environment Research Council, Cranfield, \\ Bedfordshire, MK43 0AL, UK \\ ${ }^{* *}$ now at: School of Geography, Earth and Environmental Sciences, University of Birmingham, Edgbaston, B15 2TT, UK \\ *** now at: University of York/National Centre for Atmospheric Science, Department of Chemistry, University of York, \\ York, YO10 5DD, UK \\ ***** now at: Laboratorio de Ciencias de la Atmósfera y el Clima, Consejo Superior de Investigaciones Científicas (CSIC), \\ c/Rio Cabriel S/N, 45007 Toledo, Spain \\ ****** now at: School of Chemistry, University of Leeds, Leeds, LS2 9JT, UK
}

Correspondence to: S. J.-B. Bauguitte (sbau@nerc.ac.uk)

Received: 17 July 2009 - Published in Atmos. Chem. Phys. Discuss.: 29 September 2009

Revised: 21 November 2011 - Accepted: 11 January 2012 - Published: 19 January 2012

\begin{abstract}
NO}_{\mathrm{x}}$ measurements were conducted at the Halley Research Station, coastal Antarctica, during the austral summer period 1 January-10 February 2005. A clear $\mathrm{NO}_{\mathrm{x}}$ diurnal cycle was observed with minimum concentrations close to instrumental detection limit ( $5 \mathrm{pptv})$ measured between 04:00-05:00 GMT. $\mathrm{NO}_{\mathrm{x}}$ concentrations peaked (24 pptv) between 19:00-20:00 GMT, approximately $5 \mathrm{~h}$ after local solar noon. An optimised box model of $\mathrm{NO}_{\mathrm{x}}$ concentrations based on production from in-snow nitrate photolysis and chemical loss derives a mean noon emission rate of $3.48 \times 10^{8}$ molec $\mathrm{cm}^{-2} \mathrm{~s}^{-1}$, assuming a $100 \mathrm{~m}$ boundary layer mixing height, and a relatively short $\mathrm{NO}_{\mathrm{x}}$ lifetime of $\sim 6.4 \mathrm{~h}$. This emission rate compares to directly measured values ranging from 2.1 to $12.6 \times 10^{8}$ molec $\mathrm{cm}^{-2} \mathrm{~s}^{-1}$ made on 3 days at the end of the study period. Calculations of the maximum rate of $\mathrm{NO}_{2}$ loss via a variety of conventional $\mathrm{HO}_{\mathrm{x}}$ and halogen oxidation processes show that the lifetime of $\mathrm{NO}_{\mathrm{x}}$ is predominantly controlled by halogen processing, namely $\mathrm{BrNO}_{3}$ and $\mathrm{INO}_{3}$ gas-phase formation and their subsequent heterogeneous uptake. Furthermore the presence of halogen oxides is shown to significantly perturb $\mathrm{NO}_{\mathrm{x}}$ con-
\end{abstract}

centrations by decreasing the $\mathrm{NO} / \mathrm{NO}_{2}$ ratio. We conclude that in coastal Antarctica, the potential ozone production efficiency of $\mathrm{NO}_{\mathrm{x}}$ emitted from the snowpack is mitigated by the more rapid $\mathrm{NO}_{\mathrm{x}}$ loss due to halogen nitrate hydrolysis.

\section{Introduction}

For the past two decades, polar boundary layer composition and photochemistry has been the focus of major field measurement campaigns undertaken in Arctic and Antarctic research stations.

At Alert (Nunavut, Canada), the pioneering Polar Sunrise Experiments (e.g. Barrie et al., 1994) initially prompted our attention to boundary layer ozone depletion and Arctic haze pollution events. This triggered further research, such as the Tropospheric Ozone Production around the Spring Equinox (TOPSE) airborne missions flown by the NCAR C130 research aircraft into the high Canadian Arctic during Spring 2000 (Atlas et al., 2003). Beine and co-workers provided valuable long-term monitoring trends of a variety of 
pollutants at the NILU-operated Mount Zeppelin station in Svalbard, Eastern Greenland Sea (e.g. Beine et al., 1997). Similar long-term and summer intensive measurements campaign were also conducted at the Summit station on the Greenland icecap (e.g. Dibb et al., 1998, 2002; Honrath et al., 2002).

In Antarctica, Jones et al. (1999) provided the first evidence of snowpack photochemical reactivity when measuring snow-emitted $\mathrm{NO}_{\mathrm{x}}$ at the Neumayer coastal station, whereas Davis et al. (2001) provided further observations illustrating the exceptional reactivity of the South Pole boundary layer over the Eastern Antarctic Plateau.

Most of the above-mentioned studies carried out near and over the sea-ice zone have commented on the need to include halogen chemistry in order to reconcile observations and model outputs. The presence of bromine, iodine and chlorine species and their impact on tropospheric ozone is widely acknowledged (von Glasow et al., 2004; Yang et al., 2005; Simpson et al, 2007; Read et al., 2008). Our confidence in the ubiquitous impact of halogen chemistry, despite the scarcity of halogens ground-based measurements, has been greatly improved by satellite observations of $\mathrm{BrO}$ and IO (Richter et al., 2002; Saiz-Lopez et al., 2007b; Schoenhardt et al., 2008), despite the recent results from the NASA ARCTAS and NOAA ARCPAC airborne campaigns which have highlighted some issues with $\mathrm{BrO}$ retrievals from satellites (Jacob et al., 2010; Salawitch et al., 2010).

It is now accepted that the photolysis of organic and inorganic precursors in the high (and to a lesser extent mid) latitude snowpack contributes to the release and exchange of gas-phase molecules that would hitherto not be expected in the remote polar boundary layer (Dominé and Shepson, 2002; Grannas et al., 2007). This has two main implications: (a) the polar boundary layer oxidative capacity is perturbed through ozone and $\mathrm{HO}_{\mathrm{x}}$ photochemistry (Zhou et al., 2001; Chen et al., 2004; Helmig et al., 2008; Bloss et al., 2010), and (b) these post-depositional processes affect the burial rate and chemical signature of deposited ions and trapped trace gases, hence requiring a further degree of constraint for the use of ice core proxies in paleo-atmospheric chemistry modelling studies (Wolff, 1995; Wolff et al., 2008). More recent studies of the stable isotope signature of aerosol (and snow) nitrate have illustrated the complexity in identifying $\mathrm{NO}_{\mathrm{x}}$ sources and sinks (Morin et al., 2008 and references therein). They also confirmed that $\mathrm{NO}_{\mathrm{x}}$ emissions from snow play a large role on the budget of $\mathrm{NO}_{\mathrm{x}}$ and nitrate in polar regions at the regional scale, and that $\mathrm{NO}_{\mathrm{x}}$ oxidation by halogen oxides is happening at a very large scale in the Antarctic and in the Arctic. In addition, Morin et al. (2009) recently showed that such $\mathrm{NO}_{\mathrm{x}}$ emissions not only occur from snow on ice sheets but also from snow on sea ice, as inferred from the $\delta^{15} \mathrm{~N}$ of aerosol nitrate over the frozen Weddell Sea.

In this study, we describe a set of $\mathrm{NO}_{\mathrm{x}}$ measurements conducted at the Clean Air Sector Laboratory (CASLab) at the Halley Research Station, coastal Antarctica, during the
CHemistry of the Antarctic Boundary Layer and Interface with Snow (CHABLIS) campaign (Jones et al., 2008). We focus on the austral summer intensive campaign (1 January10 February 2005) when comprehensive ancillary $\mathrm{HO}_{\mathrm{x}}$ and actinic flux measurements were available. The instrumentation and its performance are first described. We then interpret the mean $\mathrm{NO}, \mathrm{NO}_{2}$ and $\mathrm{NO}_{\mathrm{x}}$ diurnal cycles by analysing the contribution of sources and sinks with a simple steady state model. This approach contrasts with an earlier study (Anderson and Bauguitte, 2007) using a subset of the data presented here. In that study, a simple boundary layer tracer diffusion model was successfully used to reproduce the observed $\mathrm{NO}_{\mathrm{x}}$ diurnal cycle, the timing being critically dependent on $\tau$, a tracer decay rate. We, further, present results from near snow surface flux measurements of $\mathrm{NO}_{\mathrm{x}}$, and put these in the context of existing measured and model derived fluxes in the Arctic and Antarctic. Our derived $\mathrm{NO}_{\mathrm{x}}$ lifetime is compared to sink estimates employing the latest kinetic data of known oxidation processes. We analyse the $\mathrm{NO}_{\mathrm{x}}$ partitioning and assess the factors controlling the $\mathrm{NO} / \mathrm{NO}_{2}$ ratio. We finally discuss the implications of our findings for the photochemistry of the polar boundary layer, and their broader relevance to the atmospheric oxidative capacity.

\section{Methods}

\section{1 $\mathrm{NO}_{\mathrm{x}}$ instrumentation}

$\mathrm{NO}_{\mathrm{x}}$ measurements were conducted using a 2-channel chemiluminescence (CL) analyser, which evolved from the single channel system described in Cotter et al. (2003). A second CL channel was implemented to allow higher time resolution and simultaneous detection of $\mathrm{NO}$ and $\mathrm{NO}_{\mathrm{x}}$.

The design of the $\mathrm{NO}_{2}$ photolytic converter (PLC) employed in this study was inspired by the narrow-band (ca. $365 \mathrm{~nm}$ ) photolysis system described in Ryerson et al. (2000), and employs an Oriel PhotoMax lamp housing. The ellipsoid-focussed UV source used during CHABLIS was a more powerful $200 \mathrm{~W} \mathrm{Hg}$ super high-pressure arc lamp (USHIO 200DP) with water-cooled electrodes, compared with the $75 \mathrm{~W}$ Xe-Hg lamp used in previous work (Cotter et al., 2003). This yielded a threefold increase in the $\mathrm{NO}_{2}$ conversion efficiency. Spectral filtering of the UV output was achieved by means of a Pyrex window (Oriel part number 60127) as a $320 \mathrm{~nm}$ UV cut-out, located between the focussed arc and lamp housing. A KBr infrared absorbing filter (KG3, Oriel part number 51960) was also inserted to minimize heat transfer to the photolysis cell.

Given the spectral filtering employed in our PLC, we believe that the main potential photolytic interferent is from HONO (Beine et al., 2002; Ryerson et al., 2000). Using the Oriel filters transmittance data, the USHIO lamp intensity, and $\mathrm{NO}_{2}$ and $\mathrm{HONO}$ absorption cross sections from JPL evaluation 14, we estimate for our system a HONO 
interference in the $\mathrm{NO}_{2}$ PLC of $\sim 22 \%$. While an attempt to measure HONO was made during CHABLIS (Clemitshaw, 2006), subsequent assessments showed that the derived values were not consistent with observed $\mathrm{NO}_{\mathrm{x}}$ or $\mathrm{HO}_{\mathrm{x}}$ (Bloss et al., 2007, 2010). Indeed, data could only be reconciled when HONO was less than 0.22 pptv, although we note that this number relies on (i) all input data to the model being correct, and (ii) the model being complete in its representation of all the major chemical and physical processes that ultimately control the concentration of HONO. That said, even with a potential interferent of $22 \%$, at such low mixing ratios, it would seem that HONO is not likely to be a major interferent to the $\mathrm{NO}_{2}$ measurements reported here. Conclusions drawn in this paper are therefore based on the assumption that there have been no significant contributions to the measured $\mathrm{NO}_{2}$ signal from ambient HONO.

Cold ambient air was fanned from outside the CASLab and directed onto the $\mathrm{NO}_{2}$ photolysis quartz cell to maintain its wall temperature below $\sim 12{ }^{\circ} \mathrm{C}$. Without this forced air cooling, the cell heated up to temperatures in excess of $50^{\circ} \mathrm{C}$. Although thermal decomposition of PAN and/or $\mathrm{HNO}_{4}$ are potential sources of $\mathrm{NO}_{2}$, at $12{ }^{\circ} \mathrm{C}$ and below, the lifetimes of both are long compared with the cell plug-flow residence time of $<2 \mathrm{~s}$, and thus represent no significant source of interferent to our data.

The $\mathrm{NO}_{\mathrm{x}}$ measurement duty cycle was optimised as follows. The CL detectors' baseline count rates were determined by pre-chamber zeroing every 10 to $15 \mathrm{~min}$ for $60 \mathrm{~s}$. One minute averaged zero count rates were then linearly interpolated, to produce a baseline ready for subtraction from the raw signal count rate. All CL data acquired in $1 \mathrm{~Hz}$ photon-counting mode was then reduced to one minute averages after applying baseline, calibration and artefact corrections.

The NO sensitivity of the CL detectors was determined twice daily for $10 \mathrm{~min}$, with a repeat time of $13 \mathrm{~h}$, by standard addition to the ambient air matrix of a $1 \mathrm{ppmv} \mathrm{NO} / \mathrm{N}_{2}$ mixture (UK National Physical Laboratory traceable BOC certified), which is further diluted by mass flow controllers to yield 2 ppbv NO. Using the same calibration schedule, the $\mathrm{NO}_{2}$ channel photolytic conversion efficiency (CE) was determined by addition of a known mole fraction of $\mathrm{NO}_{2}$. This was achieved by gas-phase titration of the $\mathrm{NO} / \mathrm{N}_{2}$ mixture to $\mathrm{NO}_{2}$ by $\mathrm{O}_{3}$ generated from a pen-ray $\mathrm{Hg}$ lamp, and monitoring the un-titrated NO mole fraction (typically $5 \%$ ).

Detector artefact determinations were also performed twice daily with a $13 \mathrm{~h}$ repeat time staggered to that of the NO sensitivity calibrations, thereby randomising in time of day the calibration and artefact determination sequences. Instrumental artefacts were determined by overflowing the instrument inlet with scrubbed ambient air supplied by an Eco-Physics Pure Air Generator (model PAG003). Beside $\mathrm{a}-15^{\circ} \mathrm{C}$ dew point freeze-drying and ozonation/activated charcoal $\mathrm{NO}_{\mathrm{x}}$ filtering stages, this generator type also includes a $350^{\circ} \mathrm{C}$ heated Palladium catalyst scrubbing stage
Table 1. Summary of CL detector performance parameters, and nominal precision and accuracy of one minute $\mathrm{NO}_{\mathrm{x}}$ mixing ratios below 20 pptv based on known systematic errors. The $\mathrm{NO}_{2}$ systematic error includes the contribution due to the systematic error in NO. The reported $\mathrm{NO}_{2}$ artefact is the combined CL $\left(\mathrm{NO}_{\mathrm{X}}\right)$ analyser and PLC artefact.

\begin{tabular}{|c|c|c|}
\hline & NO & $\mathrm{NO}_{2}$ \\
\hline NO sensitivity, $\mathrm{Hz} \mathrm{pptv}^{-1}$ & 4.2 & 2.5 \\
\hline Background count rate, $\mathrm{Hz}$ & $300-400$ & $300-400$ \\
\hline Reaction chamber vacuum, Torr & 10 & 10 \\
\hline Detector flow-rate, std $1 \mathrm{~min}^{-1}$ & 1 & 1 \\
\hline Artefact, pptv & -2 & -6 \\
\hline $\mathrm{NO}_{2}$ photolytic $\mathrm{CE}, \%$ & $\mathrm{~N} / \mathrm{a}$ & $55-60$ \\
\hline $\begin{array}{l}\text { Limit of detection, based on } \\
\text { precision/random noise, } \\
2 \sigma \text { standard error, pptv }\end{array}$ & \pm 2.0 & \pm 6.0 \\
\hline $\begin{array}{l}\text { Accuracy based on } \\
\text { systematic errors } \\
\left(<20 \text { pptv } \mathrm{NO}_{\mathrm{X}}\right), \mathrm{pptv}\end{array}$ & \pm 1.3 & \pm 3.3 \\
\hline
\end{tabular}

for the removal of hydrocarbons. We found this method more appropriate than using " $\mathrm{NO}_{\mathrm{x}}$-free" synthetic compressed air; when comparing our pure air generator output to that of a cylinder of synthetic air (Air Products ZeroPlus grade Air), we found that the measured $\mathrm{NO}_{2}$ artefact quadrupled (NO artefact doubled) in synthetic air. For all summer data reported here, we subtracted a $2 \mathrm{pptv}$ artefact for $\mathrm{NO}$, and 6 pptv artefact for $\mathrm{NO}_{2}$.

The instrumental limit of detection was estimated from the two sigma standard error determined when averaging the $1 \mathrm{~Hz} \mathrm{NO}$ and $\mathrm{NO}_{2}$ data to one minute means. This standard error therefore corresponds to the measurement precision, and arises largely from Poisson distributed photon-counting statistics, and will decrease with further data averaging.

Overall systematic errors were estimated as the root sum of squares (rss) of all known systematic uncertainties affecting the accuracy of the measurement, namely: $\pm 3 \%$ NO calibration gas concentration (mass flow-rate controlled dilution of $1 \mathrm{ppmv} \mathrm{NO} / \mathrm{N}_{2}$ standard gas); error in linear interpolation of the $1 \mathrm{~Hz}$ baseline count rate $(0.8$ and $2.3 \mathrm{pptv}$ for $\mathrm{NO}$ and $\mathrm{NO}_{2}$, respectively); $\pm 0.4 \% \mathrm{NO}_{2} \mathrm{CE}$ determination error; instrumental artefact determination error $( \pm 1 \mathrm{pptv}$ for $\mathrm{NO}$ and \pm 3 pptv for $\mathrm{NO}_{2}$ ). Table 1 provides a summary of our instrumentation performance parameters and corresponding random and overall systematic errors for $\mathrm{NO}$ and $\mathrm{NO}_{2}$ measurements.

The final $\mathrm{NO}_{\mathrm{x}}$ data was filtered for infrequent pollution from the exhaust of the Halley Research Station generators, using the combination of a two-pass wind sector filter 


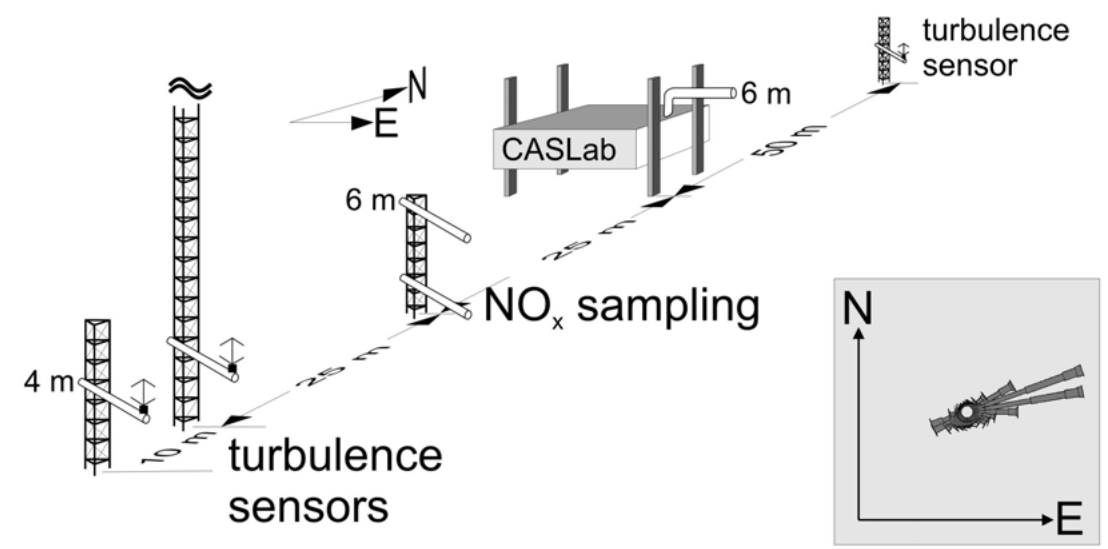

Fig. 1. Schematic of location of inlets and turbulence sensors used for $\mathrm{NO}_{\mathrm{x}}$ flux measurements during CHABLIS. The lower $\mathrm{NO}_{\mathrm{x}}$ sampling inlet, situated $25 \mathrm{~m}$ South of the CASLab, is $1.5 \mathrm{~m}$ high. The inset shows the mean wind rose at Halley.

method, station observers' logs, and $\mathrm{NO}_{\mathrm{x}}$ data itself. The first pass filter was based on the wind sector exclusion zone $\left(293\right.$ to $\left.335^{\circ}\right)$ for all wind speeds, to identify potential "discrete plumes" from the station. The second pass filter was based on the North sector exclusion zone $\left(90\right.$ to $\left.270^{\circ}\right)$ for wind speeds $<2 \mathrm{~m} \mathrm{~s}^{-1}$, to identify "dispersed plume". $\mathrm{NO}_{\mathrm{x}}$ data was then scanned for possible signs of contamination.

\subsection{Flux measurements from snow pack}

During three days at the end of the 2004/5 austral summer (1-4 February 2005), we measured coincident near snow surface $\mathrm{NO}_{\mathrm{x}}$ gradients, $\frac{\partial \mathrm{NO}_{\mathrm{x}}}{\partial z}$ (units of pptv $\mathrm{m}^{-1}$ ) and turbulent diffusivity $K$ (units of $\mathrm{m}^{2} \mathrm{~s}^{-1}$ ), which give estimates of vertical $\mathrm{NO}_{\mathrm{x}}$ flux, $F_{\mathrm{NO}_{\mathrm{x}}}$, according to:

$F_{\mathrm{NO}_{\mathrm{x}}}=K \frac{\partial \mathrm{NO}_{\mathrm{x}}}{\partial z}$

$F_{\mathrm{NO}_{\mathrm{x}}}$ is therefore in units of pptv $\mathrm{m} \mathrm{s}^{-1}$, a concentration velocity. The $\mathrm{NO}_{\mathrm{x}}$ analyser sampled sequentially from two inlets mounted on a mast $\sim 25 \mathrm{~m}$ South of the CASLab (see Fig. 1). The upper and lower $\mathrm{NO}_{\mathrm{x}}$ inlets were 6.0 and $1.5 \mathrm{~m}$ above the snow surface. Ambient air was drawn back to the CASLab via two $\sim 25$ m blacked-out $1 / 4^{\prime \prime}$ od PFA Teflon tubes. The residence time of the ambient air matrix in the PFA transfer lines was measured to be $\sim 14 \mathrm{~s}$, by spiking high $\mathrm{NO} / \mathrm{N}_{2}$ concentrations at the inlet tips. The flow rate through the transfer lines was maintained at $\sim 51 \mathrm{~min}^{-1}$ with a throttled air pump (GAST model DOA-P725-BN).

For $\mathrm{NO}_{\mathrm{x}}$ flux measurements, the instrument duty cycle was modified as follows: $10 \mathrm{~min}$ sampling for a particular inlet height, consisting of 9 min measure, and 1 min zeroing, then inlet height swap. The synchronisation of the analyser duty cycle and inlet height switching valves was achieved within 1 to $2 \mathrm{~s}$.

A $30 \mathrm{~m}$ turbulence profiling mast was a further $25 \mathrm{~m}$ South of the $\mathrm{NO}_{\mathrm{x}}$ sampling mast (Fig. 1) with turbulence and mean micro-meteorological sensors mounted in a vertical array. The instrument set included a sonic anemometer/thermometer at $4 \mathrm{~m}$ height above snow. See Anderson and Neff (2008) for a detailed description of the $30 \mathrm{~m}$ mast.

Similar sonic anemometry was located $10 \mathrm{~m}$ South and $100 \mathrm{~m}$ North of the $30 \mathrm{~m}$ mast, in order to estimate spatial variability of turbulence measurements at the $4 \mathrm{~m}$ level and hence give confidence limits for the diffusivity estimates at the $\mathrm{NO}_{\mathrm{x}}$ inlets.

\subsection{Photolysis rates}

The $2 \pi$ spectro radiometer used for measuring actinic fluxes is described in Jones et al. (2008). Here we focus on the data processing employed to derive the photolysis rates of atmospheric $\mathrm{NO}_{2}$ and in-snow nitrate ions, needed for our model study.

\subsection{1 $J \mathrm{NO}_{2}^{\text {total }}$}

In order to derive the $4 \pi$ integrated $J \mathrm{NO}_{2}^{\text {total }}$, we used the $2 \pi$ downwelling $J \mathrm{NO}_{2}^{\downarrow}$ (measured routinely), and the $2 \pi$ upwelling $J \mathrm{NO}_{2}^{\uparrow}$ (measured very occasionally). The latter was used to adjust $J \mathrm{NO}_{2}^{\downarrow}$ according to the actinic flux ratio (see Jones et al., 2008). For cloudy sky conditions (okta $>6.5$; cloud cover being estimated as how many eighths of the sky, known by meteorologists as oktas, are obscured by cloud; ranging from completely clear, 0 oktas, through to completely overcast, 8 oktas), we used the actinic flux ratio $J \mathrm{NO}_{2}^{\downarrow} / J \mathrm{NO}_{2}^{\uparrow}$ equal to 0.98 . For less diffuse light conditions $($ okta $<6.5)$, the ratio was calculated using the solar zenith angle (SZA) parameterisation described in Jones et al. (2008). The correction of the ratio calculated as a function of SZA, to a constant 0.98 actinic flux ratio, was found to be between $\pm 3 \%$ and $\pm 14 \%$. The lowest correction figures occurred at low zenith angles and hence high actinic fluxes, while the largest corrections were obtained at high zenith 
angles. The mean solar noon $J \mathrm{NO}_{2}$ value for the CHABLIS summer campaign was $\sim 1.93 \times 10^{-2} \mathrm{~s}^{-1}$.

\subsubsection{In-snow $J$ (Nitrate $)^{\downarrow}$}

Estimating and measuring the photolysis rate of nitrate ions in snow is a difficult task (Wolff et al., 2002; Qiu et al., 2002; Fisher et al., 2005). In Wolff et al. (2002) and Jones et al. (2011), $\mathrm{NO}_{\mathrm{x}}$ emission rates from snow were estimated using in-snow nitrate ion actinic flux as a function of depth, using a snow pack radiative transfer model (Grenfell, $1991)$, with the spectral irradiance input, $E^{\downarrow}(\lambda)$, calculated using the NCAR/ACD radiative transfer model TUV. In their trace gas diffusion modelling study, Anderson and Bauguitte (2007) used global shortwave irradiance measurements, $G$, for approximating the column integrated in-snow actinic flux for nitrate, defined as $\int J(\text { Nitrate })^{\downarrow} d z$. They argue the case for the approximate linearity of the transfer function $G \rightarrow \int J(\text { Nitrate })^{\downarrow} d z$.

The above methodologies suffer from a variety of shortfalls. In the two former studies, inherent uncertainties are introduced by employing the TUV radiative transfer model output $E^{\downarrow}(\lambda)$ for the flux computation. In the latter study, $G$ is poorly spectrally resolved for the nitrate ion, and the linear relationship of the proxy is dependent upon zenith angle.

In this study, we approximate in-snow nitrate ion actinic fluxes using $2 \pi$ downwelling, spectrally resolved, atmospheric actinic flux measurements $F(\lambda)^{\downarrow}$, which we believe provide a more robust proxy. The methodology has nonetheless its own sources of uncertainties which we discuss here.

$J$ (Nitrate $)^{\downarrow}$ photolysis rates were computed using nitrate ion cross sections, in liquid phase at room temperature, taken from Burley and Johnston (1992), and quantum efficiencies in ice from the formula of Chu and Anastasio (2003), calculated at $5 \mathrm{~K}$ intervals from 258 to $278 \mathrm{~K}$.

A further correction of the in-snow photolysis rate is needed, to account for the fact that we only measure downwelling flux $F(\lambda)^{\downarrow}$, whereas the in-snow flux is the sum of downwelling and upwelling terms. By analogy with the fluxes inside the top of dense cloud (Madronich, 1987), upwelling and downwelling fluxes are everywhere equal in snow, and in the case of diffuse light when one expects equal downwelling fluxes just below and just above the snow surface, the total in-snow flux is $2 \times F^{\downarrow}$.

Because the relationship between flux and irradiance for diffuse illumination is given by $F^{\downarrow}=2 \times E^{\downarrow}$, the total insnow flux is $4 \times E^{\downarrow}$. In the case of direct light (clear sky and no Rayleigh scattering), Lee-Taylor and Madronich (2002) show that the same relationship holds a few $\mathrm{cm}$ down inside the snow pack, irrespective of SZA. Above the snow, $E^{\downarrow}=F^{\downarrow} \times \cos (\mathrm{SZA})$, and between 1 January and 10 February 2005 , the solar noon SZA varied from 52.6 to $61.4^{\circ}$. The resulting proportionality factor in clear sky conditions and low solar noon SZA will therefore be in the range 0.48 to 0.61 , so that the total in-snow flux is 1.91 to $2.44 \times F^{\downarrow}$.
However we argue that the $F^{\downarrow}=2 \times E^{\downarrow}$ relationship still holds to some extent in more direct light conditions, due to Rayleigh scattering of the atmosphere at a sea-level site, especially in the near-UV part of the spectrum where nitrate ions photolyse $(280-320 \mathrm{~nm})$. During the CHABLIS summer intensive campaign, the cloud cover was greater than 6.5 okta for $\sim 60 \%$ of the time. Hence we choose total insnow flux to be $2 \times F^{\downarrow}$, where $F^{\downarrow}$ is our $j$ Nitrate $\downarrow$ calculated from our measured $F(\lambda)^{\downarrow}$, and accept a potential for error of perhaps $20 \%$ near noon on a few days with fully clear skies.

For the CHABLIS austral summer campaign, we computed a mean solar noon $j$ Nitrate $\downarrow$ photolysis rate of $\sim 1.19 \times 10^{-7} \mathrm{~s}^{-1}$, so that our in-snow flux would be $\sim 2.38 \times 10^{-7} \mathrm{~s}^{-1}$. This is approximately a factor 5 smaller than the $\sim 12.5 \times 10^{-7} \mathrm{~s}^{-1}$ values measured by actinometry tubes deployed at Summit Greenland on surface snow on 8 June by Qiu et al. (2002), although the authors do not report absolute measurements uncertainty.

\subsection{Ancillary data sets}

For model calculations, we employed various data sets acquired for the period 1 January to 10 February 2005 at the Halley Research Station. For surface ozone and meteorology parameters, we used the data sets highlighted in Jones et al. (2008). $\mathrm{OH}$ and $\mathrm{HO}_{2}$ data from Bloss et al. (2007) were used for $\mathrm{NO}_{\mathrm{x}}$ lifetime calculations. Mean diurnally varying $\mathrm{IO}$ and $\mathrm{BrO}$ concentrations from LP-DOAS observations (Saiz-Lopez et al., 2007a) were used for $\mathrm{NO} / \mathrm{NO}_{2}$ ratio calculations. The mean noon-time $\mathrm{IO}$ and $\mathrm{BrO}$ mixing ratios were, respectively, 4.3 and $3.8 \mathrm{pptv}$ (A. Saiz-Lopez and A. Mahajan, personal communication, 2006). As the sun remained above the horizon $\left(\mathrm{SZA}<90^{\circ}\right)$ throughout the CHABLIS summertime study ( $24 \mathrm{~h}$ daylight), "night-time" IO and $\mathrm{BrO}$ were always above the DOAS instrument detection limit.

Unless otherwise stated in the text, all kinetic data used for model calculations in this study were taken from JPL Evaluation Number 15 (Sander et al., 2006).

\section{$3 \mathrm{NO}_{\mathrm{x}}$ observations}

\subsection{Timeseries}

The hourly mean $\mathrm{NO}$ and $\mathrm{NO}_{2}$ mixing ratios (pptv) between 1 January and 10 February 2005 , calculated from one minute pollution-filtered data, are plotted in Fig. 2.

NO mixing ratios, plotted in red, rarely go above $20 \mathrm{pptv}$ and display a diurnal cycle, anti-correlating with SZA, plotted in grey. This concentration range ( 0 to $40 \mathrm{pptv}$ ) is in contrast to the high concentrations (up to $500 \mathrm{pptv}$ ) reported at South Pole over continental Antarctica (Davis et al., 2001, 2004), but in agreement with other coastal Antarctic NO observations (up to $15 \mathrm{pptv}$ ) made at the Neumayer Station (Jones et al., 2000; Weller et al., 2002). 


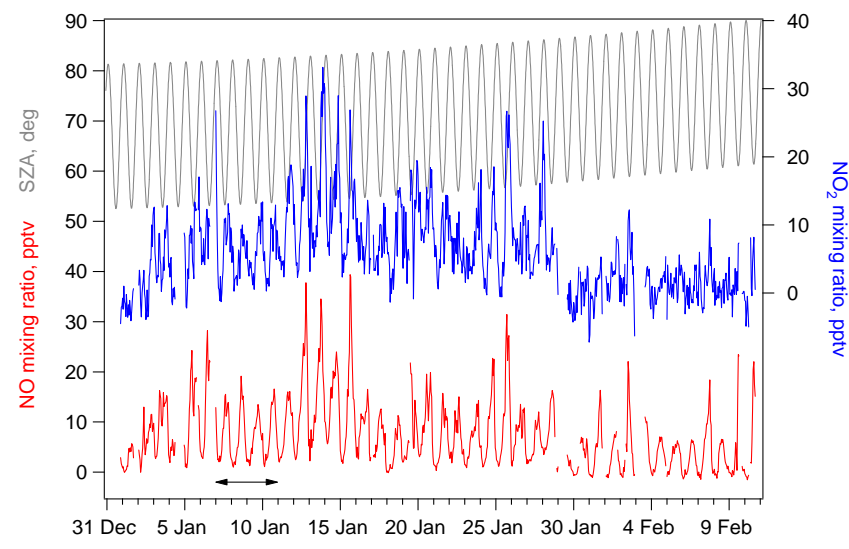

Fig. 2. Mixing ratios (pptv) of $\mathrm{NO}$ (red, left-hand scale), $\mathrm{NO}_{2}$ (blue, right-hand scale) and solar zenith angle (grey, left-hand scale) from 1 January to 10 February 2005. These $\mathrm{NO}$ and $\mathrm{NO}_{2}$ values are one hourly means of the one minute pollution-filtered data. The black arrow indicates the four-day blizzard conditions, when wind speeds in excess of $15 \mathrm{~m} \mathrm{~s}^{-1}$ and blowing snow were experienced.

$\mathrm{NO}_{2}$ mixing ratios, plotted in blue against the right-hand axis with a positive offset for clarity, also show a diurnal cycle, although it is not as distinct as that of NO. At times, particularly at the beginning and end of the 40 day measurement period, $\mathrm{NO}_{2}$ hourly means appear negative. This is due to the incorporation in our analysis of all $\mathrm{NO}_{2}$ data, regardless of values below detection limit resulting from poor artefact correction, and hence increased systematic uncertainty when atmospheric $\mathrm{NO}_{2}$ approaches the detection limit of the instrument ( $\sim 6 \mathrm{pptv}$, see Table 1$)$.

\subsection{Mean diurnal cycle}

Using the observations of Fig. 2, the hourly mean diurnal cycles of $\mathrm{NO}, \mathrm{NO}_{2}$ and $\mathrm{NO}_{\mathrm{x}}$, averaged over the whole dataset, were derived and plotted in Fig. 3. Error bars for each hourly mean are systematic errors: 1.3 and 3.3 pptv for $\mathrm{NO}$ and $\mathrm{NO}_{2}$ respectively, and their rss for $\mathrm{NO}_{\mathrm{x}}$. Both $\mathrm{NO}$ and $\mathrm{NO}_{2}$, and hence $\mathrm{NO}_{\mathrm{x}}$, exhibit clear diurnal cycles, a phenomenon which has been widely reported in previous polar studies (Jones et al., 1999; Jacobi et al., 2000; Ridley et al., 2000; Beine et al., 2002; Honrath et al., 2002; Weller et al., 2002). In our study, the $\mathrm{NO}_{\mathrm{x}}$ mean diurnal cycle is very pronounced. Maximum concentrations of $\sim 24$ pptv are observed between 19:00 and 20:00 GMT, and minimum concentrations close to instrumental detection limit are observed in the early hours between 05:00 and 06:00 GMT. It is worth noting that maximum $\mathrm{NO}_{\mathrm{x}}$ values occur $\sim 5 \mathrm{~h}$ after the local solar noon at 13:45 GMT. This diurnal variation is in line with that reported for summertime $\mathrm{NO}_{\mathrm{x}}$ measurements at Neumayer, another coastal Antarctic site, with $\mathrm{NO}_{\mathrm{x}}$ maxima of $\sim 25 \mathrm{pptv}$ at around 19:00 GMT (Jones et al., 1999; Weller et al., 1999). Similarly, Honrath et al. (2002) report $\mathrm{NO}_{\mathrm{x}}$ diurnal cycles at

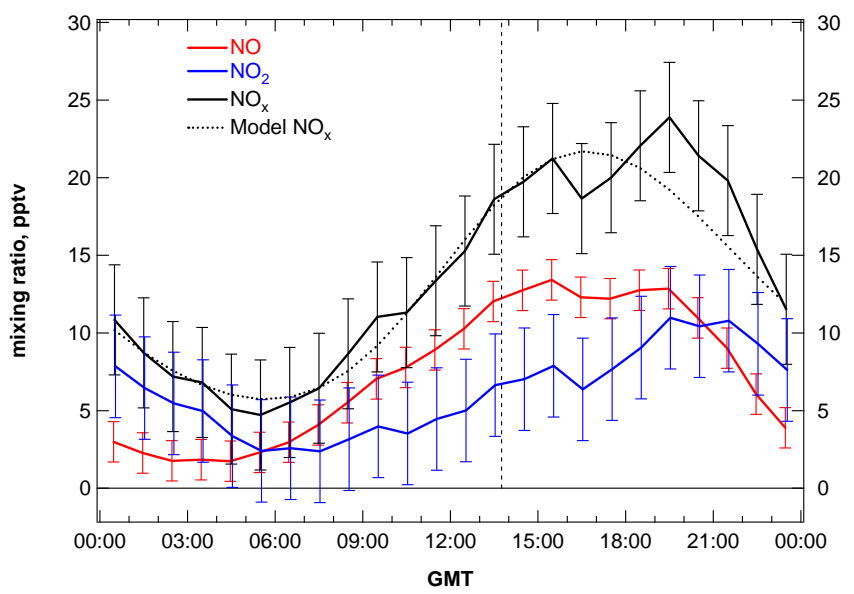

Fig. 3. Hourly mean diurnal cycle of $\mathrm{NO}$ (red), $\mathrm{NO}_{2}$ (blue) and $\mathrm{NO}_{\mathrm{x}}$ (black) for 1 January to 10 February 2005, compiled from the one minute pollution-filtered master dataset. Error bars are systematic errors (uncertainties from Table 1). The dotted black line (Model $\mathrm{NO}_{\mathrm{x}}$ ) corresponds to the Steady State $\mathrm{NO}_{\mathrm{x}}$ calculations (see text). The vertical dashed line indicates local noon, 13:45 h.

Summit for summer 1999 and 2000, with maximum median values of $\sim 40$ and $\sim 60$ pptv, respectively.

\section{Steady State $\mathrm{NO}_{\mathrm{x}}$ calculations}

\subsection{Model description}

To understand the factors driving the shape and timing of the observed $\mathrm{NO}_{\mathrm{x}}$ diurnal cycle, we consider a simple model based on our current understanding of the photochemistry of polar tropospheric $\mathrm{NO}_{\mathrm{x}}$ (Honrath et al., 1999; Cotter et al., 2003; Jones et al., 2011). $\mathrm{NO}_{\mathrm{x}}$ is emitted from the snow pack at a rate proportional to the photolysis of nitrate ions in the snow $F$ (Nitrate), equal to $2 \times$ our measured $j$ Nitrate $^{\downarrow}$ (see Sect. 2.3), with proportionality constant $\alpha$. We balance this term with a constant loss rate defined by a daily mean $\mathrm{NO}_{\mathrm{x}}$ lifetime $\tau$ which represents all unspecified losses of $\mathrm{NO}_{\mathrm{x}}$. Our simple model parameterisation is expressed in Eq. (2) below:

$$
\frac{\partial\left[\mathrm{NO}_{\mathrm{x}}\right]}{\partial t}=\left(\alpha E(\text { Nitrate })^{\downarrow}\right)-\left(\frac{\left[\mathrm{NO}_{\mathrm{x}}\right]}{\tau}\right)
$$

The production term scaling factor $\alpha$ has the same dimension as $\left[\mathrm{NO}_{\mathrm{x}}\right]$, while $E$ (Nitrate) $)^{\downarrow}$ is in $\mathrm{s}^{-1}$.

To model $\mathrm{NO}_{\mathrm{x}}$ concentrations, we can integrate Eq. (2) forwards until a diurnal steady state is reached in typically 2 days. We optimize the value of $\alpha$ and $\tau$ by minimising a cost function between the hourly model values and the hourly observed values to provide the best possible fit to the diurnal hourly observations in Fig. 3, as described in Eq. (3):

$$
\text { Cost }=\sum_{\text {hours } 0-24} \mid[\text { Model }]-[\text { Obs }] \mid
$$


This minimisation is achieved using the Powell method described in section 10.5 of Press et al. (1993). Figure 3 shows the comparison between the observed diurnal variation of $\mathrm{NO}_{\mathrm{x}}$ (solid black line) and the best fit values of the model (dashed black line). After optimization the model simulation reproduces many of the features observed, including the early morning $\mathrm{NO}_{\mathrm{x}}$ minimum, and the $\mathrm{NO}_{\mathrm{x}}$ peak after solar noon.

Uncertainties for modelled $\mathrm{NO}_{\mathrm{x}}, \alpha$ and $\tau$, arise from the combined uncertainties of the input parameters of Eq. (2), namely observed $\mathrm{NO}_{\mathrm{x}}$ and $E$ (Nitrate) $)^{\downarrow}$, and to a lesser extent errors propagated from the mathematical fitting method employed in Eq. (3). The minimum uncertainty for observed $\mathrm{NO}_{\mathrm{x}}$ is $\sim 15 \%$, as showed by the systematic error bars for the highest mixing ratios in Fig. 3. Uncertainties for $E$ (Nitrate) $)^{\downarrow}$ could be as high as $20 \%$ near noon on a few days with fully clear skies as discussed in Sect. 2.3.2 (insnow $\left.J(\text { Nitrate })^{\downarrow}\right)$. Observed and modelled $\mathrm{NO}_{\mathrm{x}}$ therefore agree within the above combined uncertainties.

\subsection{Results: $\mathrm{NO}_{\mathrm{x}}$ production term}

Snowpack $\mathrm{NO}_{\mathrm{x}}$ fluxes can be derived from both indirect and direct methods. Using the indirect method described above, we compute a value of $5516 \mathrm{pptv}$ for $\alpha$, and a value of $6.38 \mathrm{~h}$ for $\tau$. Assuming a $100 \mathrm{~m}$ summertime boundary layer mixing height (annual mean height for Halley is $\sim 70 \mathrm{~m}$, Jones et al., 2008), the product $\alpha E$ (Nitrate) ${ }^{\downarrow}$ corresponds to a mean noon emission rate of $3.48 \times 10^{8}$ molec cm$~^{-2} \mathrm{~s}^{-1}$ for the 1 January to 10 February 2005 . This emission rate would scale linearly with a changing boundary layer height, which we note is is both difficult to define and highly variable during Antarctic summer (Anderson and Neff, 2008).

In their indirect-method study using a snow pack radiative transfer model methodology, Jones et al. (2011) estimated a daily average emission rate of $2.42 \times 10^{8}$ molec cm $^{-2} \mathrm{~s}^{-1}$ for 18 January 2005 during CHABLIS, with a noon-time rate of $5.5 \times 10^{8}$ molec $\mathrm{cm}^{-2} \mathrm{~s}^{-1}$ (unpublished data).

Evans et al. (2003) modelled the High Canadian Arctic $\left(>55^{\circ} \mathrm{N}\right)$ observations made during the TOPSE airborne campaign in March-May 2000. Their daily averaged modelderived $\mathrm{NO}_{\mathrm{x}}$ flux was equivalent to $3.6 \times 10^{8} \mathrm{~cm}^{2} \mathrm{~s}^{-1}$ for a $200 \mathrm{~m}$ boundary layer height.

For a direct assessment, we conducted $\mathrm{NO}_{\mathrm{x}}$ flux measurements for several days at the end of the CHABLIS summer campaign (see Methods). The $20 \mathrm{~min}$ averaged $\mathrm{NO}_{\mathrm{x}}$ gradients, defined as $\frac{\partial \mathrm{NO}_{\mathrm{x}}}{\partial z}$, where $\partial z=4.5 \mathrm{~m}\left(\mathrm{NO}_{\mathrm{x}}\right.$ sampling inlets height differential) are presented in panel a of Fig. 4. Coincident averaged surface diffusivity $K\left(\mathrm{~m}^{2} \mathrm{~s}^{-1}\right)$ is plotted in panel $\mathrm{b}$, as well as the $10 \mathrm{~min}$ averaged wind speed $v\left(\mathrm{~m} \mathrm{~s}^{-1}\right)$ to illustrate the local meteorology during the flux measurement period. $K$ was defined as the product $k \times z \times U_{*}$, where $k=0.4$ is the dimensionless von Karman constant, $U_{*}$ is the friction velocity $\left(\mathrm{m} \mathrm{s}^{-1}\right)$ defined as the cross product of sonic anemometer data, and $z=4 \mathrm{~m}$ is the height of the turbulence

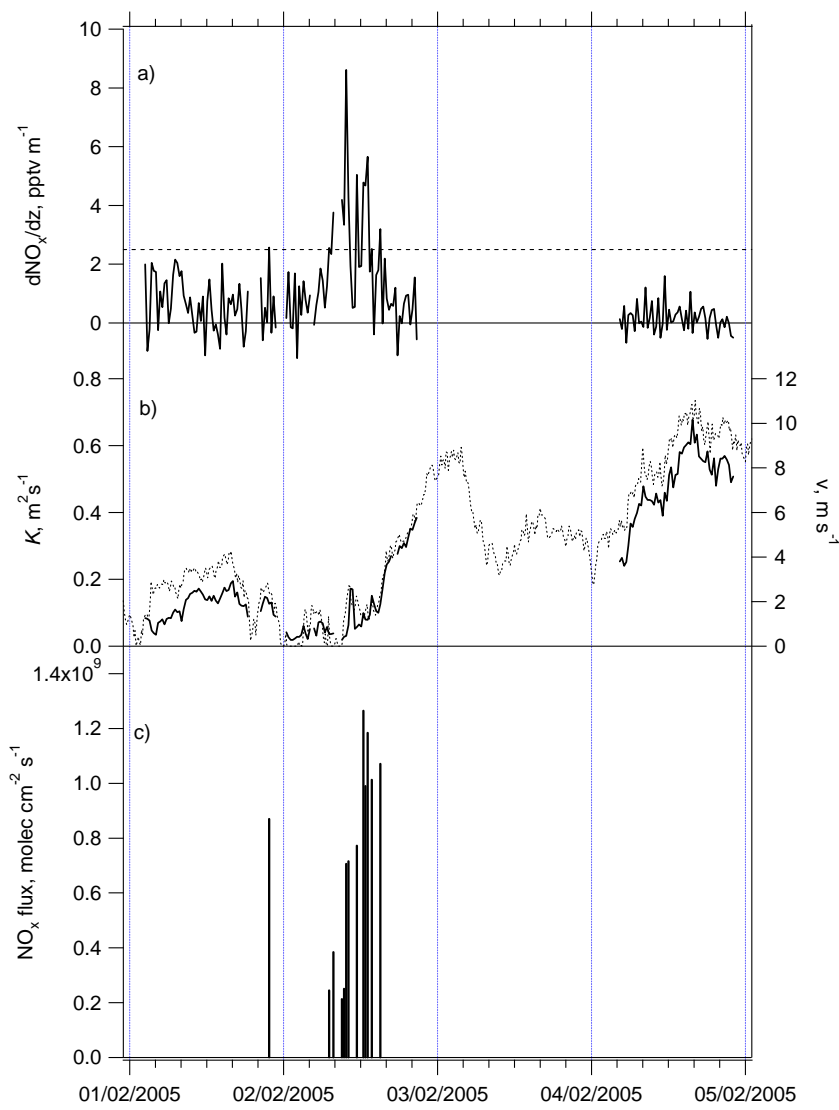

Fig. 4. (a) 20 min averaged $\mathrm{NO}_{\mathrm{x}}$ gradients $\left(\frac{\partial \mathrm{NO}_{\mathrm{x}}}{\partial z}\right)$ estimated from the 1.5 and $6 \mathrm{~m}$ high inlets $\mathrm{NO}_{\mathrm{x}}$ measurements; the horizontal dashed line $\left(2.5 \mathrm{pptv} \mathrm{m}^{-1}\right)$ corresponds to the $2 \sigma$ precision of the gradient measurements; (b) $20 \mathrm{~min}$ averaged surface diffusivities $(K)$ estimated from the friction velocities $U_{*}$ at $4 \mathrm{~m}$ height (solid line, left-hand axis), and $10 \mathrm{~min}$ averaged wind speeds (dotted line, right-hand axis); (c) 20 min averaged $\mathrm{NO}_{\mathrm{x}}$ fluxes expressed as the product $\frac{\partial \mathrm{NO}_{\mathrm{x}}}{\partial z} \times K$, filtered for gradients less than $2.5 \mathrm{pptv} \mathrm{m}^{-1} \mathrm{de}-$ tection threshold. $\mathrm{NO}_{\mathrm{x}}$ gradient were not measured during 3 February 2005 due to instrument downtime/maintenance.

sensor (see Fig. 1). The $\mathrm{NO}_{\mathrm{x}}$ flux is defined by the product of the gradient and surface diffusivity (Anderson and Neff, 2008). The uncertainty of $U_{*}$, and therefore $K$, was estimated using $10 \mathrm{~min}$ averaged sonic anemometry data during a day with near neutral boundary layer conditions (similar to 2 February 2005). We computed the relative difference between the $U_{*}$ measurement at the $30 \mathrm{~m}$ mast, to its measurement $10 \mathrm{~m}$ South and $100 \mathrm{~m}$ North (see Fig. 1 and Sect. 2.2). The above assessment yielded a measurement uncertainty for $U_{*}$ at $4 \mathrm{~m}$ of $\pm 3 \%$.

We evaluate the $\frac{\partial \mathrm{NO}_{\mathrm{x}}}{\partial z}$ precision from the $2 \sigma$ precision of our $\mathrm{NO}_{\mathrm{x}}$ data around solar noon on 4 February 2005, when low $\mathrm{NO}_{\mathrm{x}}$ gradients $\left(<1.6 \mathrm{pptv} \mathrm{m}^{-1}\right)$ and high diffusivities were experienced. $\frac{\partial \mathrm{NO}_{\mathrm{x}}}{\partial z}$ is a differential measurement and therefore does not suffer from the instrumental artefacts discussed in Sect. 2.1. The $2 \sigma$ precision of $1 \mathrm{~Hz}$ measurements 
Table 2. Summary of $\mathrm{NO}_{\mathrm{x}}$ fluxes derived through direct measurements in Arctic and Antarctic studies.

\begin{tabular}{|c|c|c|c|}
\hline Location & Date & $\begin{array}{l}\mathrm{NO}_{\mathrm{x}} \text { flux, } \\
\text { molec } \mathrm{cm}^{-2} \mathrm{~s}^{-1}\end{array}$ & Reference \\
\hline \multicolumn{4}{|l|}{ Antarctic measurements } \\
\hline $\begin{array}{l}\text { Neumayer } \\
70^{\circ} 39^{\prime} \mathrm{S}, 8^{\circ} 15^{\prime} \mathrm{W}, 42 \mathrm{~m}\end{array}$ & 5-7 Feb 1999 & $\begin{array}{l}\sim 3(+0.3 /-0.9) \times 10^{8} \\
(\text { noon maxima) }\end{array}$ & Jones et al. (2001) \\
\hline $\begin{array}{l}\text { South Pole } \\
2835 \mathrm{~m}\end{array}$ & 26-30 Nov 2000 & $\begin{array}{l}3.9 \pm 0.4 \times 10^{8} \\
\text { (average over period) }\end{array}$ & Oncley et al. (2004) \\
\hline $\begin{array}{l}\text { Halley V } \\
75^{\circ} 35^{\prime} \mathrm{S}, 26^{\circ} 40^{\prime} \mathrm{W}, 37 \mathrm{~m}\end{array}$ & $2 \mathrm{Feb} 2005$ & $\begin{array}{l}12.6 \times 10^{8} \text { (noon maxima) } \\
7.3 \times 10^{8} \\
(07: 05-15: 05 \text { GMT mean })\end{array}$ & This Study (Fig. 4) \\
\hline \multicolumn{4}{|l|}{ Arctic measurements } \\
\hline $\begin{array}{l}\text { Summit, Greenland } \\
72^{\circ} 36^{\prime} \mathrm{N}, 38^{\circ} 30^{\prime} \mathrm{W}, 3200 \mathrm{~m}\end{array}$ & 5 Jun-3 Jul 2001 & $\begin{array}{l}2.5 \times 10^{8} \\
\text { (daily average) }\end{array}$ & Honrath et al. (2002) \\
\hline $\begin{array}{l}\text { Alert, Nunavut, Canada, } \\
82^{\circ} 30^{\prime} \mathrm{N}, 62^{\circ} 18^{\prime} \mathrm{W}, 220 \mathrm{~m}\end{array}$ & 9-25 April 2000 & $\begin{array}{l}\geq 6.7 \times 10^{8} \\
(\text { noon maxima) }\end{array}$ & Beine et al. (2002) \\
\hline
\end{tabular}

over a 9 min sampling period at one sampling height (see Sect. 2.2) for $\mathrm{NO}$ and $\mathrm{NO}_{2}$ is \pm 11.6 and \pm 38.8 pptv respectively, decreasing to \pm 0.5 and $\pm 1.7 \mathrm{pptv}$ for a $9 \mathrm{~min}$ average. The rss of the precisions of two 9 min $\mathrm{NO}_{\mathrm{x}}$ measurements (two heights) yields a $2 \sigma$ precision for $\frac{\partial \mathrm{NO}_{\mathrm{x}}}{\partial z}$ of $\pm 2.5 \mathrm{pptv} \mathrm{m}^{-1}$. This detection threshold is represented by the horizontal dashed line in panel a of Fig. 4.

The largest uncertainty in our $\mathrm{NO}_{\mathrm{x}}$ flux is arising from the $\mathrm{NO}_{\mathrm{x}}$ gradient term. Most of the $\mathrm{NO}_{\mathrm{x}}$ gradient measurements for 1 and 4 February 2005 fall below the 2.5 pptv m $^{-1}$ threshold, and were filtered out in the $20 \mathrm{~min}$ averaged $\mathrm{NO}_{\mathrm{x}}$ fluxes (in molec $\mathrm{cm}^{-2} \mathrm{~s}^{-1}$ ) plotted in panel c of Fig. 4 .

The mean $\mathrm{NO}_{\mathrm{x}}$ flux measured during 2 February 2005 between 07:05 and 15:05 GMT was 7.3 $\times 10^{8}$ molec $^{-2} \mathrm{~s}^{-1}$, with a noon maximum of $12.6 \times 10^{8}$ molec $\mathrm{cm}^{-2} \mathrm{~s}^{-1}$. For the broader context, Table 2 shows $\mathrm{NO}_{\mathrm{x}}$ fluxes derived from direct measurements in other polar studies. Simple quantitative comparisons are not reliable due to the varying parameters that may affect the $\mathrm{NO}_{\mathrm{x}}$ fluxes in the different studies (time of year/day, latitude, altitude, cloudiness, nitrate ion snow content). The most similar site to Halley of those listed in Table 2, is Neumayer, where, nonetheless, considerably smaller fluxes were measured.

Accurate flux derivations become extremely important for modelling calculations aiming to scale processes up for regional assesements. A long-duration flux study at a single location that can properly assess flux variability with time, as well as compare direct and indirect assessment methods, would therefore seem extremely timely.

\section{$5 \mathrm{NO}_{\mathrm{x}}$ lifetime calculations}

\subsection{Model description}

Our estimated $\mathrm{NO}_{\mathrm{x}}$ emission flux is consistent with previous studies. However our estimated daily mean $\mathrm{NO}_{\mathrm{x}}$ lifetime of $6.38 \mathrm{~h}$ appears relatively short given known $\mathrm{NO}_{\mathrm{x}}$ losses. $\mathrm{Ri}$ dley et al. (2000) and Beine et al. (2002) did not derive $\mathrm{NO}_{\mathrm{x}}$ lifetimes from their respective measurements at Alert. However, the pronounced diurnal cycle of $\mathrm{NO}_{\mathrm{x}}$ concentrations reported by Ridley et al. (2000), with noon-maximum, may suggest $\mathrm{NO}_{\mathrm{x}}$ lifetimes shorter than $4 \mathrm{~h}$ (Evans et al., 2003). Davis et al. (2004) report enhanced $\mathrm{NO}_{\mathrm{x}}$ lifetimes at South Pole. Although $\mathrm{NO}_{\mathrm{x}}$ concentrations at South Pole are much more elevated than at Halley (up to 800 pptv), Davis et al. report box modelled $\mathrm{NO}_{\mathrm{x}}$ lifetimes (loss to $\mathrm{HO}_{\mathrm{x}}$ and $\mathrm{HNO}_{4}$ ) as function of $\mathrm{NO}_{\mathrm{x}}$ concentration and found that for concentrations below $\sim 170$ pptv, their estimated $\mathrm{NO}_{\mathrm{x}}$ lifetimes remain constant at $\sim 8 \mathrm{~h}$.

Using available observations, we consider the maximum rate of $\mathrm{NO}_{2}$ loss via a variety of conventional $\mathrm{HO}_{\mathrm{x}}$ and halogen oxidation processes:

$$
\begin{aligned}
& \mathrm{NO}_{2}+\mathrm{OH}+M \rightarrow \mathrm{HNO}_{3}+M \\
& \mathrm{NO}_{2}+\mathrm{O}_{3} \rightarrow \mathrm{NO}_{3}+\mathrm{O}_{2}\left(+\mathrm{NO}_{2} \rightarrow \mathrm{N}_{2} \mathrm{O}_{5}\right) \\
& \mathrm{NO}_{2}+\mathrm{HO}_{2}+M \leftrightarrow \mathrm{HNO}_{4}+M \\
& \mathrm{NO}_{2}+\mathrm{IO}+M \rightarrow \mathrm{INO}_{3}+M \\
& \mathrm{NO}_{2}+\mathrm{BrO}+M \rightarrow \mathrm{BrNO}_{3}+M
\end{aligned}
$$




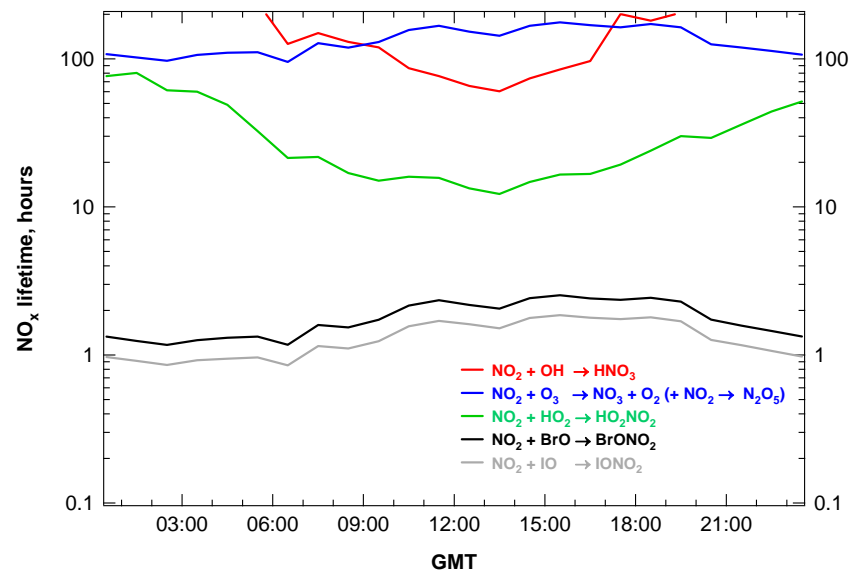

Fig. 5. Diurnal $\mathrm{NO}_{\mathrm{x}}$ lifetimes, derived from calculations of known $\mathrm{NO}_{2}$ oxidation-loss pathways.

All of these reactions represent $\mathrm{NO}_{2}$ losses. To convert the $\mathrm{NO}_{2}$ losses to a $\mathrm{NO}_{\mathrm{x}}$ lifetime we use Eq. (4) (Seinfeld and Pandis, 1998):

$\tau_{\mathrm{NO}_{\mathrm{x}}}=\left(k_{i}[\text { Oxidant }]\right)^{-1}\left(1+\frac{[\mathrm{NO}]}{\left[\mathrm{NO}_{2}\right]}\right)$

where $k_{i}$ is the oxidation rate constant for reaction $R_{i} . \mathrm{HO}_{\mathrm{x}}$ observations reported in Bloss et al. (2007) were used for Reactions (1) and (3). For Reactions (4) and (5), we assumed a constant 3 pptv IO and 3 pptv BrO mixing ratio, consistent with the DOAS summertime observations conducted by Saiz-Lopez et al. (2007a) during CHABLIS.

\subsection{Results}

Equation (4) now allows us to calculate the $\mathrm{NO}_{\mathrm{x}}$ lifetimes for each reaction and how they vary around the day. This is shown in Fig. 5. The conventional $\mathrm{NO}_{\mathrm{x}}$ loss pathways, $\mathrm{HNO}_{3}$ and $\mathrm{NO}_{3}$ formation represented by the red and blue lines, are much too slow to be significant. They suggest $\mathrm{NO}_{\mathrm{x}}$ lifetimes of the order of at least $100 \mathrm{~h}$ whereas the observations suggest a lifetime of $\sim 6 \mathrm{~h}$.

$\mathrm{HNO}_{4}$ formation (green line) offers a potentially more efficient loss process with a mean $\mathrm{NO}_{\mathrm{x}}$ lifetime of the order of $20 \mathrm{~h}$, still significantly longer than that derived from the observations. Once sequestrated in the $\mathrm{HNO}_{4}$ reservoir, further aerosol uptake and hydrolysis is required to ultimately remove $\mathrm{NO}_{\mathrm{x}}$. However, $\mathrm{HNO}_{4}$ can undergo both photolysis and thermal decomposition prior to aerosol uptake. Using the radiative transfer model described in Saiz-Lopez et al. (2008), we estimate a maximum noon-time $J \mathrm{HNO}_{4}$ value of $5.05 \times 10^{-6} \mathrm{~s}^{-1}$, corresponding to a photolysis lifetime greater than 2 days, which is therefore negligible. Using the termolecular reaction and equilibrium constants for Reaction (3) from the JPL Evaluation Number 15 (Sander et al., 2006), and the mean diurnal temperatures and pressures for summertime CHABLIS, we compute $\mathrm{HNO}_{4}$ lifetimes to thermal decomposition ranging from 8 to $15 \mathrm{~min}$. This proves that during our study, the $\mathrm{HNO}_{4}$ reservoir was too thermally labile to play a significant role in $\mathrm{NO}_{\mathrm{x}}$ sequestration and further loss.

Even with the low concentrations of $\mathrm{IO}$ and $\mathrm{BrO}$ observed during summertime CHABLIS, the production of halogen nitrates appears to be the most significant sink for $\mathrm{NO}_{\mathrm{x}}$, as indicated by the black and grey lines in Fig. 5. The $\mathrm{NO}_{\mathrm{x}}$ lifetime to these reactions is very short, with a combined diurnal mean lifetime approaching half an hour, fast enough to explain the steady state derived diurnal mean lifetime of $\sim 6 \mathrm{~h}$. However, for the production of halogen nitrates to act as a net $\mathrm{NO}_{\mathrm{x}}$ sink, the halogen nitrates must hydrolyse on the surface of aerosol. This process competes with their photolysis. These two processes are considered next.

\section{3 $\mathrm{XNO}_{3}$ heterogeneous loss lifetime calculations}

We estimate the lifetime of halogen nitrates to their heterogeneous uptake in the aerosol phase. This treatment is similar to that used in the 1-D box modelling study of SaizLopez et al. (2008) and zero-D box modelling study of Bloss et al. (2010), whereby the uptake to aerosol represents irreversible loss from the gas phase, and subsequent condensedphase (hydrolysis) reactions are not specified. We use the free molecular transfer theory and estimate the heterogeneous uptake rate constant $k_{\text {het }}$ using Eq. (5):

$k_{\text {het }}=\frac{\bar{c} \gamma \mathrm{SA}}{4}$

where $\bar{c}$ is the mean gas velocity, $\gamma$ is the reaction probability, and SA is the aerosol surface area.

Physical properties of aerosol particles were not measured during CHABLIS. However aerosol surface area measurements were reported by Davison et al. (1996) on board the Royal Research Ship Bransfield moored along the Brunt Ice Shelf near Halley, between 21 and 31 December 1992. The mean geometric aerosol surface area for measurements made south of $58^{\circ} \mathrm{S}$ with an ASASP-X volatility analyser was $\sim 0.32 \pm 0.01 \times 10^{-7} \mathrm{~cm}^{2} \mathrm{~cm}^{-3}$. The authors argue that the ASASP-X technique only measures the "dry" geometric aerosol SA for the accumulation mode size range 0.1 to $0.4 \mu \mathrm{m}$ diameter, and therefore does not represent the full aerosol size range $(0.1$ to $3 \mu \mathrm{m})$. The actual SA is likely to be higher and varying with relative humidity, up to 4 times for $75-80 \%$ RH. The studies of Saiz-Lopez et al. (2008) and Bloss et al. (2010) used an SA of $10^{-7} \mathrm{~cm}^{2} \mathrm{~cm}^{-3}$, and we used the same value, in line with the above findings.

We assume the same dimensionless $\gamma$ reaction probability for both $\mathrm{BrNO}_{3}$ and $\mathrm{INO}_{3}$ of 0.8 (Sander et al., 2006). Using Eq. (5), we compute daily mean lifetimes to heterogeneous uptake of 0.7 and $0.8 \mathrm{~h}$ for $\mathrm{BrNO}_{3}$ and $\mathrm{INO}_{3}$, respectively. Given the lifetimes derived from the gas-phase formation of $\mathrm{XNO}_{3}$ (black and grey lines in Fig. 5), the rate limiting step 


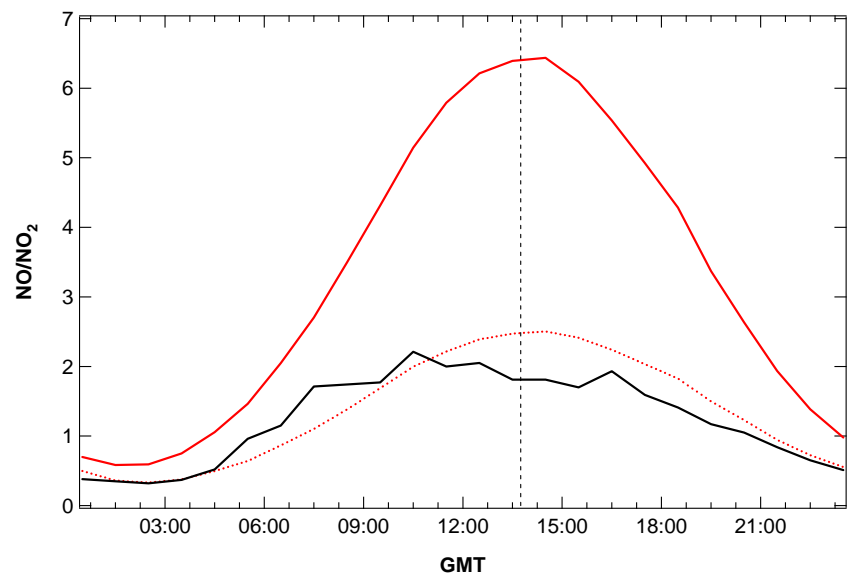

Fig. 6. Solid black line: hourly mean diurnal cycle of observed $\mathrm{NO} / \mathrm{NO}_{2}$ ratios. Solid red line: $\mathrm{NO} / \mathrm{NO}_{2}$ ratios calculated using "classic" Leighton relationship (ozone as sole oxidant). Dotted red line: $\mathrm{NO} / \mathrm{NO}_{2}$ ratios calculated using "extended" Leighton relationship (ozone plus diurnally varying $\mathrm{IO}$ and $\mathrm{BrO}$ oxidants). The vertical dashed line indicates local noon, 13:45 h.

for $\mathrm{NO}_{\mathrm{x}}$ loss is the gas-phase formation. These lifetimes now need to be compared to the loss due to photolysis.

\section{$5.4 \mathrm{XNO}_{3}$ photolysis effects}

We use the parameterisation of Bloss et al. (2010) for estimating the photolysis rates of halogen species, based on the TUV radiative transfer model and our $J \mathrm{NO}_{2}^{\text {total }}$ measurements. At solar noon, we find that $\mathrm{INO}_{3}$ and $\mathrm{BrNO}_{3}$ photolyse rapidly (lifetimes $\sim 2-5 \mathrm{~min}$ ), whereas during low insolation hours the $\mathrm{BrNO}_{3}$ and $\mathrm{INO}_{3}$ photolysis lifetimes increase to $\sim 1 \mathrm{~h}$ and $\sim 20 \mathrm{~min}$ respectively, thus approaching the time scales for $\mathrm{XNO}_{3}$ hydrolysis. Although the photolysis of the halogen nitrates dominates over their heterogeneous loss during high insolation hours, at greater solar zenith angles the two processes are able to compete efficiently, allowing the heterogeneous uptake of halogen nitrates to occur rapidly, precisely at the time when one expects $\mathrm{NO}_{\mathrm{x}}$ net loss pathways to dominate, as indicated by the sharp drop in $\mathrm{NO}_{\mathrm{x}}$ mixing ratios in the mean diurnal cycle in Fig. 3.

\section{$6 \mathrm{NO} / \mathrm{NO}_{2}$ ratios}

\subsection{Observed NO to $\mathrm{NO}_{2}$ ratios}

We now turn our attention from the evolution of the $\mathrm{NO}_{\mathrm{x}}$ concentration to that of the $\mathrm{NO}$ to $\mathrm{NO}_{2}$ partitioning. We derive observed hourly $\mathrm{NO} / \mathrm{NO}_{2}$ ratios from 1 min data, as shown by the solid black line in Fig. 6 . The highest ratios $(2.2 \pm 0.2$, $2 \sigma$ standard error) are measured between 10:00 and 11:00, whereas the lowest ratios $(0.32 \pm 0.04)$ occur between 02:00 and 03:00. We expect our observed $\mathrm{NO} / \mathrm{NO}_{2}$ diurnal cycle to be centred about solar noon (i.e. maximum $J \mathrm{NO}_{2}$ ). However the inclusion of all $\mathrm{NO}_{2}$ data (i.e. also close to/below detection limit), is affecting the shape of our diurnal cycle (see Sect. 3). Here we focus chiefly on the magnitude of the ratios.

\section{2 "Classic" Leighton relationship}

Classically the $\mathrm{NO}$ to $\mathrm{NO}_{2}$ ratio is defined solely by the steady state reaction between $\mathrm{NO}$ and $\mathrm{O}_{3}$, and $\mathrm{NO}_{2}$ photolysis; this relationship is known as the Leighton relationship (Leighton, 1961). The reaction rates of $\mathrm{NO}+\mathrm{HO}_{2}$ and $\mathrm{NO}+\mathrm{RO}_{2}$ are negligible compared to the reaction with $\mathrm{O}_{3}$ $\left(<2 \%\right.$ contribution to $\mathrm{NO} \rightarrow \mathrm{NO}_{2}$ cycling). Hence:

$\frac{[\mathrm{NO}]}{\left[\mathrm{NO}_{2}\right]}=\frac{J \mathrm{NO}_{2}^{\text {total }}}{k_{\mathrm{O}_{3}}\left[\mathrm{O}_{3}\right]}$

The $\mathrm{NO} / \mathrm{NO}_{2}$ ratios calculated by this method are shown in Fig. 6 as the solid red line. This reveals a large discrepancy between observed and calculated $\mathrm{NO} / \mathrm{NO}_{2}$, with calculated ratios being almost three times higher at local noon.

\section{3 "Extended" Leighton relationship - halogen effects}

The reaction between halogen oxide radicals (XO) and $\mathrm{NO}$ is rapid and has been shown in previous studies to impact $\mathrm{NO} / \mathrm{NO}_{2}$ ratios (e.g. Ridley et al., 2000; Evans et al., 2003; Ridley and Orlando, 2003; Morin et al., 2007; Saiz-Lopez et al., 2008). The discrepancy between observed and the "classic" Leighton relationship ratios reflects the halogen oxides reacting with $\mathrm{NO}$ to create $\mathrm{NO}_{2}$. Equation (6) can be altered to reflect this extra chemistry given by the "extended" Leighton relationship:

$\frac{[\mathrm{NO}]}{\left[\mathrm{NO}_{2}\right]}=\frac{J \mathrm{NO}_{2}^{\text {total }}}{k_{\mathrm{O}_{3}}\left[\mathrm{O}_{3}\right]+k_{\mathrm{BrO}}[\mathrm{BrO}]+k_{\mathrm{IO}}[\mathrm{IO}]}$

Using diurnally varying $\mathrm{BrO}$ and $\mathrm{IO}$ (see Methods) and Eq. (7), we calculate $\mathrm{NO} / \mathrm{NO}_{2}$ ratios as shown in Fig. 6 by the dotted red line. The inclusion of halogen oxides in our calculations markedly decreases the ratio and brings it into agreement with our observations. Thus halogen oxides play a highly significant role in decreasing the $\mathrm{NO} / \mathrm{NO}_{2}$ ratio.

Noon-time $\mathrm{NO} / \mathrm{NO}_{2}$ ratios measured at Neumayer in February 1999 (Jones et al., 2000) were even lower $(\sim 0.75)$ than our observed ratios, suggesting that the impact of $\mathrm{XO}$ chemistry in controlling $\mathrm{NO}_{\mathrm{x}}$ partitioning at Neumayer might be even more pronounced than at Halley.

At Alert in the high Canadian Arctic, Ridley et al. (2000) observed diurnally varying $\mathrm{NO} / \mathrm{NO}_{2}$ in March-April 1998, with ratios reaching up to $\sim 0.5$ at low SZA $\left(75^{\circ}\right)$. The authors calculated a $\leq 10 \mathrm{pptv}$ burden for radicals $\left(\mathrm{HO}_{2}+\mathrm{RO}_{2}+\mathrm{BrO}+\mathrm{ClO}\right)$ in order to sustain their observed low ratios. It is worth remembering that these observations were carried out in springtime, at a time when $\mathrm{BrO}$ is expected to be at its peak. 
Our results also corroborate those of the Saiz-Lopez et al. (2008) halogen chemical and transport modelling study, in which their model was constrained with a $\mathrm{NO}_{\mathrm{x}}$ summertime flux of $2 \times 10^{8}$ molec $\mathrm{cm}^{-2} \mathrm{~s}^{-1}$, assumed to be produced by photochemistry of snow pack nitrate. Without halogen chemistry, they estimate a solar noon $\mathrm{NO} / \mathrm{NO}_{2}$ ratio of $\sim 3.3$, which then drops to $\sim 1.8$ after implementation of the halogen chemistry scheme.

\section{Discussion}

We showed that our observed mean $\mathrm{NO}_{\mathrm{x}}$ diurnal cycle can be reproduced using a simple chemical steady state $\mathrm{NO}_{\mathrm{x}}$ analysis. A credible estimate for the mean $\mathrm{NO}_{\mathrm{x}}$ emission rate from snow was derived. Employing up-to-date kinetics data and known $\mathrm{NO}_{2}$ oxidation mechanisms, we identified and verified viable $\mathrm{NO}_{\mathrm{x}}$ chemical loss pathways leading to short $\mathrm{NO}_{\mathrm{x}}$ lifetimes. Both our methodology in the present paper and that of Anderson and Bauguitte (2007) (discussed earlier) use simplified models with inherent caveats. While assuming a fixed $100 \mathrm{~m}$ boundary layer depth for deriving our model $\mathrm{NO}_{\mathrm{x}}$ flux (see Sect. 4.2), with "near-instant" vertical mixing, we clearly ignore the atmospheric boundary layer physics highlighted in the Anderson and Bauguitte (2007) study. Conversely, the latter physics-based study acknowledges under-representing the highly complex underlying $\mathrm{NO}_{\mathrm{x}}-\mathrm{HO}_{\mathrm{x}}$ and halogen chemistry. It is most probable that a truer representation of our observations requires a combined approach from the chemistry and physics point-ofview.

Our $\mathrm{NO}_{\mathrm{x}}$ lifetime study identified apparent $\mathrm{NO}_{2}$ oxidation loss pathways involving halogen nitrates, and their aerosol uptake. Although the parameterisation of these processes entails uncertainties (aerosol surface area, reaction probability), we show that the kinetics are sufficiently fast to explain the relatively short $\mathrm{NO}_{\mathrm{x}}$ lifetimes initially derived from our steady state calculations.

Our assessment did not include chlorine chemistry, which may play a role, but which we are unable to examine in a constrained way due to lack of observations. For known chemistry, we note that gamma for chlorine nitrate hydrolysis is small $\sim 0.002$ compared to the 0.3 value for bromine nitrate. It would therefore be a less significant $\mathrm{NO}_{\mathrm{x}}$ sink event if $\mathrm{ClNO}_{3}$ was at the same concentration as $\mathrm{BrNO}_{3}$. The rate constant for $\mathrm{ClO}+\mathrm{NO}$ is half that of $\mathrm{BrO}+\mathrm{NO}$ so is less likely to impact the $\mathrm{NO} / \mathrm{NO}_{2}$ ratio. The possibility clearly remains, however, that other chemical channels exist for moving chlorine into its active forms, and if so, there is a high chance that they would be active under the conditions experienced during CHABLIS, i.e. in coastal Antarctica during summer.

It is noteworthy that the $\mathrm{NO}_{\mathrm{x}}$ diurnal cycle does not appear to be affected by extreme changes in the local atmosphere and snow surface, such as during the 7-10 January 2005 pe- riod, when the blizzard wind speeds in excess of $15 \mathrm{~m} \mathrm{~s}^{-1}$ and blowing snow were experienced (see Fig. 2). Even under such extreme conditions, neither the amplitude nor the timing of the diurnal maximum are outside the range of more quiescent conditions. In these very turbulent atmospheric conditions, we expect well-diffused light photolysis of windblown snow particles, and therefore $\mathrm{NO}_{\mathrm{x}}$ production would be occurring. Snow pack wind pumping would presumably maintain an efficient $\mathrm{NO}_{\mathrm{x}}$ diffusion and mixing in the overlying boundary layer. Equally the process of $\mathrm{NO}_{\mathrm{x}}$ loss by heterogeneous uptake to the aerosol phase of halide nitrates would still be ongoing with enhanced aerosol scavenging.

The impact of the source of $\mathrm{NO}_{\mathrm{x}}$ from snow photolysis on the Antarctic boundary layer composition might be expected to lead to $\mathrm{O}_{3}$ production; however in coastal regions the halogens tend to mitigate this effect leading to a reduced $\mathrm{NO}_{\mathrm{x}}$ lifetime and a reduction in the $\mathrm{NO} / \mathrm{NO}_{2}$ ratio. Away from marine influences, the impact of photolysis of snow phase nitrate is significantly different as can be seen at the South Pole (Crawford et al., 2001; Jones and Wolff, 2003; Helmig et al., 2008; Oltmans et al., 2008; Legrand et al., 2009). The geographical extent to which halogens mitigate the impact is as yet unknown.

The link between $\mathrm{NO}_{\mathrm{x}}$ emissions from snow and local oxidation by halogens and heterogeneous loss to $\mathrm{BrNO}_{3}$ was also clearly demonstrated using a very different approach, namely isotopic measurements of nitrate both in the Arctic and Antarctic (Morin et al., 2008; Morin et al., 2009).

The impact of halogens on $\mathrm{HO}_{\mathrm{x}}$ and $\mathrm{O}_{\mathrm{x}}$ chemistry in coastal Antarctica, the Arctic and mid-latitudes is well documented (e.g. Sjostedt et al., 2007; Grannas et al., 2007; Simpson et al., 2007; Saiz-Lopez et al., 2008; Read et al., 2008). However, the impact on $\mathrm{NO}_{\mathrm{x}}$ is less well characterised. It seems clear from this study that, in coastal Antarctica, the impact on $\mathrm{NO}_{\mathrm{x}}$ lifetime and partitioning is also significant, although this impact is highly dependent on atmospheric dynamics. For instance, Legrand et al. (2009) found no evidence of active halogen chemistry at the French Dumont d'Urville Research Station in coastal Antarctica, where air masses are mostly brought from the Antarctic Plateau through katabatic flow. Our results may however signal an influence that is active beyond the Antarctic coastal region and into the global marine boundary layer on climate-relevant parameters such $\mathrm{O}_{3}$ and $\mathrm{OH}$.

\section{Conclusions}

At Halley, the source of $\mathrm{NO}_{\mathrm{x}}$ is mainly a local photochemically driven emission from the snow pack. However, observed concentrations peak relatively close to solar noon $(\sim 5 \mathrm{~h})$ suggesting a much shorter lifetime than is possible through simple $\mathrm{HO}_{\mathrm{x}}-\mathrm{NO}_{\mathrm{x}}$ photochemistry alone. The shorter lifetime $(\sim 6 \mathrm{~h})$ is consistent with halogen photochemistry, notably conversion into halogen nitrate. Given the lack of 
an observational constraint, the fate of these halogen nitrates is uncertain, though heterogeneous uptake onto aerosol and subsequent deposition seems a viable mechanism in this region to return nitrate to the snow surface. This is a dominant uncertainty in evaluating the $\mathrm{NO}_{\mathrm{x}}$ budget. We found the $\mathrm{HNO}_{4}$ heterogeneous loss channel for $\mathrm{NO}_{\mathrm{x}}$ to be negligible in the relatively warm summertime, although it may play a more significant competing role in the colder springtime.

The halogen chemistry also significantly perturbs the NO to $\mathrm{NO}_{2}$ ratio resulting in much lower $\mathrm{NO}$ concentrations than would be otherwise observed, for instance in inland Antarctica. The presence of halogens in the coastal Antarctic region, and presumably in the Arctic, therefore mitigates the atmospheric response of the photochemical $\mathrm{NO}_{\mathrm{x}}$ emissions from snow.

Acknowledgements. We wish to thank the Halley 2004/05 overwintering staff, in particular Craig Nicholls and Vanessa O'Brien for being so understanding and patient in the overcrowded Clean Air Sector Laboratory. We also thank Steve Colwell for providing meteorological data. We wish to thank Samuel Morin for encouraging and constructive comments during the review process. We are also grateful to one anonymous referee who reviewed this paper over a number of exchanges, and whose comments undoubtedly improved the manuscript. This work was funded by the UK Natural Environment Research Council Antarctic Funding Initiative (grant number NER/G/S/2001/00010) and by the British Antarctic Survey core-funded projects SAGES-AIR and CACHE-CEFAC.

Edited by: W. T. Sturges

\section{References}

Anderson, P. S. and Bauguitte, S. J.-B.: Behaviour of tracer diffusion in simple atmospheric boundary layer models, Atmos. Chem. Phys., 7, 5147-5158, doi:10.5194/acp-7-5147-2007, 2007.

Anderson, P. S. and Neff, W. D.: Boundary layer physics over snow and ice, Atmos. Chem. Phys., 8, 3563-3582, doi:10.5194/acp-83563-2008, 2008.

Barrie, L. A., Bottenheim, J. W., and Hart, W. R.: Polar Sunrise Experiment 1992 (PSE-1992) - Preface, J. Geophys. Res., 99, 25313-25314, 1994.

Beine, H. J., Jaffe, D. A., Herring, J. A., Kelley, J. A., Krognes, T., and Stordal, F.: High-latitude springtime photochemistry. Part I: $\mathrm{NO}_{\mathrm{x}}$, PAN and ozone relationships, J. Atmos. Chem., 27, 127153, 1997.

Beine, H. J., Honrath, R. E., Dominé, F., Simpson, W. R., and Fuentes, J. D.: $\mathrm{NO}_{\mathrm{x}}$ during background and ozone depletion periods at Alert: Fluxes above the snow surface, J. Geophys. Res., 107, 4584, doi:10.1029/2002JD002082, 2002.

Bloss, W. J., Lee, J. D., Heard, D. E., Salmon, R. A., Bauguitte, S. J.-B., Roscoe, H. K., and Jones, A. E.: Observations of $\mathrm{OH}$ and $\mathrm{HO}_{2}$ radicals in coastal Antarctica, Atmos. Chem. Phys., 7, 4171-4185, doi:10.5194/acp-7-4171-2007, 2007.

Bloss, W. J., Camredon, M., Lee, J. D., Heard, D. E., Plane, J. M. C., Saiz-Lopez, A., Bauguitte, S. J.-B., Salmon, R. A., and Jones, A. E.: Coupling of $\mathrm{HO}_{\mathrm{x}}, \mathrm{NO}_{\mathrm{x}}$ and halogen chemistry in the antarctic boundary layer, Atmos. Chem. Phys., 10, 1018710209, doi:10.5194/acp-10-10187-2010, 2010.

Burley, J. D. and Johnston, H. S.: Ionic mechanisms for heterogeneous stratospheric reactions and ultraviolet photoabsorption cross-sections for $\mathrm{NO}_{2}^{+}, \mathrm{HNO}_{3}$, and $\mathrm{NO}_{3}^{-}$in sulfuric-acid, Geophys. Res. Lett., 19, 1359-1362, 1992.

Chen, G., Davis, D., Crawford, J., Mauldin, L., Eisele, F., Huey, G., Slusher, D., Tanner, D. J., Dibb, J., Buhr, M., Hutterli, M. A., McConnell, J., Lefer, B., Shetter, R., Blake, D., Lombardi, $\mathrm{K}$., and Arnoldy, J.: A reassessment of $\mathrm{HO}_{\mathrm{x}}$ chemistry based on observations recorded during ISCAT 2000, Atmos. Environ., 38, 5451-5462, 2004.

Chu, L. and Anastasio, C.: Quantum yields of hydroxyl radical and nitrogen dioxide from the photolysis of nitrate on ice, J. Phys. Chem. A, 107, 9594-9602, 2003.

Clemitshaw, K. C.: Coupling between the Tropospheric Photochemistry of Nitrous Acid (HONO) and Nitric Acid $\left(\mathrm{HNO}_{3}\right)$, Environ. Chem., 3, 31-34, doi:10.1071/EN05073, 2006.

Cotter, E. S. N., Jones, A. E., Wolff, E. W., and Bauguitte, S. J.B.: What controls photochemical $\mathrm{NO}$ and $\mathrm{NO}_{2}$ production from Antarctic snow? Laboratory investigation assessing the wavelength and temperature dependence, J. Geophys. Res., 108, 4147, doi:10.1029/2002JD002602, 2003.

Crawford, J. H., Davis, D. D., Chen, G., Buhr, M., Oltmans, S., Weller, R., Mauldin, L., Eisele, F., Shetter, R., Lefer, B., Arimoto, R., and Hogan, A.: Evidence for photochemical production of ozone at the South Pole surface, Geophys. Res. Lett., 28, 3641-3644, 2001.

Davis, D., Chen, G., Buhr, M., Arimoto, R., Hogan, A., Eisele, F., Mauldin, L., Tanner, D., Shetter, R., Lefer, B., and McMurry, P.: Unexpected High Levels of NO Observed at South Pole, Geophys. Res. Lett., 28, 3625-3628, 2001.

Davis, D., Nowak, J. B., Chen, G., Buhr, M., Crawford, J., Lenschow, D., Lefer, B., Shetter, R., Eisele, F., Mauldin, L., and Hogan, A.: South Pole $\mathrm{NO}_{\mathrm{x}}$ Chemistry: An assessment of factors controlling variability and absolute levels, Atmos. Environ., 38, 5375-5388, 2004.

Davison, B., Hewitt, C. N., O’Dowd, C. D., Lowe, J. A., Smith, M. H., Schwikowski, M., Baltensperger, U., and Harrison, R. M.: Dimethyl sulphide, methane sulfonic acid and physicochemical aerosol properties in Atlantic air from the United Kingdom to Halley Bay, J. Geophys. Res., 101, 22855-22867, 1996.

Dibb, J. E., Talbot, R. W., Munger, J. W., Jacob, D. J., and Fan, S.M.: Air-snow exchange of $\mathrm{HNO}_{3}$ and $\mathrm{NO}_{\mathrm{y}}$ at Summit, Greenland, J. Geophys. Res., 103, 3475-3486, 1998.

Dibb, J. E., Arsenault, M., Peterson, M. C., and Honrath, R. E.: Fast nitrogen oxide chemistry in Summit, Greenland snow, Atmos. Environ., 36, 2501-2511, 2002.

Dominé, F. and Shepson, P. B.: Air-snow interactions and atmospheric chemistry, Science, 297, 1506-1510, 2002.

Evans, M. J., Jacob, D. J., Atlas, E., Cantrell, C. A., Eisele, F., Flocke, F., Fried, A., Mauldin, R. L., Ridley, B. A., Wert, B., Talbot, R., Blake, D., Heikes, B., Snow, J., Walega, J., Weinheimer, A. J., and Dibb, J.: Coupled evolution of $\mathrm{BrO}_{\mathrm{x}}-\mathrm{ClO}_{\mathrm{X}}-$ $\mathrm{HO}_{\mathrm{x}}-\mathrm{NO}_{\mathrm{x}}$ chemistry during bromine-catalyzed ozone depletion events in the arctic boundary layer, J. Geophys. Res., 108, 8368, doi:10.1029/2002JD002732, 2003.

Fisher, F. N., King, M. D., and Lee-Taylor, J.: Extinction of UV-visible radiation in wet midlatitude (maritime) snow: 
Implications for increased $\mathrm{NO}_{\mathrm{x}}$ emission, J. Geophys. Res., 110, D21301, doi:10.1029/2005JD005963, 2005.

Grannas, A. M., Jones, A. E., Dibb, J., Ammann, M., Anastasio, C., Beine, H. J., Bergin, M., Bottenheim, J., Boxe, C. S., Carver, G., Chen, G., Crawford, J. H., Dominé, F., Frey, M. M., Guzmán, M. I., Heard, D. E., Helmig, D., Hoffmann, M. R., Honrath, R. E., Huey, L. G., Hutterli, M., Jacobi, H. W., Klán, P., Lefer, B., McConnell, J., Plane, J., Sander, R., Savarino, J., Shepson, P. B., Simpson, W. R., Sodeau, J. R., von Glasow, R., Weller, R., Wolff, E. W., and Zhu, T.: An overview of snow photochemistry: evidence, mechanisms and impacts, Atmos. Chem. Phys., 7, 4329-4373, doi:10.5194/acp-7-4329-2007, 2007.

Grenfell, T. C.: A radiative-transfer model for sea ice with vertical structure variations, J. Geophys. Res., 96, 16991-17001, 1991.

Helmig, D., Johnson, B., Oltmans, S. J., Neff, W., Eisele, F., and Davis, D. D.: Elevated ozone in the boundary-layer at South Pole, Atmos. Environ., 42, 2788-2803, 2008.

Honrath, R. E., Peterson, M. C., Guo, S., Dibb, J. E., Shepson, P. B., and Campbell, B.: Evidence of $\mathrm{NO}_{\mathrm{x}}$ Production Within or Upon Ice Particles in the Greenland Snowpack, Geophys. Res. Lett., 26, 695-698, 1999.

Honrath, R. E., Lu, Y., Peterson, M. C., Dibb, J. E., Arsenault, M. A., Cullen, N. J., and Steffen, K.: Vertical fluxes of $\mathrm{NO}_{\mathrm{x}}$, HONO, and $\mathrm{HNO}_{3}$ above the snowpack at Summit, Greenland, Atmos. Environ., 36, 2629-2640, 2002.

Jacob, D. J., Crawford, J. H., Maring, H., Clarke, A. D., Dibb, J. E., Emmons, L. K., Ferrare, R. A., Hostetler, C. A., Russell, P. B., Singh, H. B., Thompson, A. M., Shaw, G. E., McCauley, E., Pederson, J. R., and Fisher, J. A.: The Arctic Research of the Composition of the Troposphere from Aircraft and Satellites (ARCTAS) mission: design, execution, and first results, Atmos. Chem. Phys., 10, 5191-5212, doi:10.5194/acp-10-5191-2010, 2010.

Jacobi, H.-W., Weller, R., Jones, A. E., Anderson, P. S., and Schrems, O.: Peroxyacetyl nitrate (PAN) concentrations in the Antarctic troposphere measured during the photochemical experiment at Neumayer (PEAN'99), Atmos. Environ., 34, 52355247, 2000.

Jones, A. E. and Wolff, E. W.: An analysis of the oxidation potential of the South Pole boundary layer and the influence of stratospheric ozone depletion, J. Geophys. Res., 108, 4565, doi:10.1029/2003JD003379, 2003.

Jones, A. E., Weller, R., Wolff, E. W., and Jacobi, H.-W.: Speciation and Rate of Photochemical $\mathrm{NO}$ and $\mathrm{NO}_{2}$ Production in Antarctic Snow, Geophys. Res. Lett., 27, 345-348, 2000.

Jones, A. E., Weller, R., Anderson, P. S., Jacobi, H.-W., Wolff, E. W., Schrems, O., and Miller, H.: Measurements of $\mathrm{NO}_{\mathrm{x}}$ emissions from the Antarctic snowpack, Geophys. Res. Lett., 28, 1499-1502, 2001.

Jones, A. E., Wolff, E. W., Salmon, R. A., Bauguitte, S. J.-B., Roscoe, H. K., Anderson, P. S., Ames, D., Clemitshaw, K. C., Fleming, Z. L., Bloss, W. J., Heard, D. E., Lee, J. D., Read, K. A., Hamer, P., Shallcross, D. E., Jackson, A. V., Walker, S. L., Lewis, A. C., Mills, G. P., Plane, J. M. C., Saiz-Lopez, A., Sturges, W. T., and Worton, D. R.: Chemistry of the Antarctic Boundary Layer and the Interface with Snow: an overview of the CHABLIS campaign, Atmos. Chem. Phys., 8, 3789-3803, doi:10.5194/acp-8-3789-2008, 2008.

Jones, A. E., Wolff, E. W., Ames, D., Bauguitte, S. J.-B., Clemitshaw, K. C., Fleming, Z., Mills, G. P., Saiz-Lopez, A., Salmon,
R. A., Sturges, W. T., and Worton, D. R.: The multi-seasonal $\mathrm{NO}_{\mathrm{y}}$ budget in coastal Antarctica and its link with surface snow and ice core nitrate: results from the CHABLIS campaign, Atmos. Chem. Phys., 11, 9271-9285, doi:10.5194/acp-11-92712011, 2011.

Lee-Taylor, J. and Madronich, S.: Calculation of actinic fluxes with a coupled atmosphere-snow radiative transfer model, J. Geophys. Res., 107, 4796, doi:10.1029/2002JD002084, 2002.

Legrand, M., Preunkert, S., Jourdain, B., Gallée, H., Goutail, F., Weller, R., and Savarino, J.: Year round record of surface ozone at coastal (Dumont d'Urville) and inland (Concordia) sites in East Antarctica, J. Geophys. Res., 114, D20306, doi:10.1029/2008JD011667, 2009.

Leighton, P. A.: Photochemistry of Air Pollution, Vol. IX, Physical Chemistry: A Series of Monographs, edited by: Hutchinson, E. and Ryssleberghe, P. V., Academic Press, New York, 1961.

Li, Z., Friedl, R. R., Moore, S. B., and Sander, S. P.: Interaction of peroxynitric acid with solid $\mathrm{H}_{2} \mathrm{O}$ ice, J. Geophys. Res. 101, 6795-6802, 1996.

Madronich, S.: Photodissociation in the Atmosphere: 1. Actinic Flux and the Effects of Ground Reflections and Clouds, J. Geophys. Res., 92, 9740-9752, 1987.

Morin, S., Savarino, J., Bekki, S., Gong, S., and Bottenheim, J. W.: Signature of Arctic surface ozone depletion events in the isotope anomaly $\left(\Delta^{17} \mathrm{O}\right)$ of atmospheric nitrate, Atmos. Chem. Phys., 7 , 1451-1469, doi:10.5194/acp-7-1451-2007, 2007.

Morin, S., Savarino, J., Frey, M. M., Yan, N., Bekki, S., Bottenheim, J. W., and Martins, J. M. F.: Tracing the Origin and Fate of $\mathrm{NO}_{\mathrm{x}}$ in the Arctic Atmosphere Using Stable Isotopes in Nitrate, Science, 322, 730, doi:10.1126/science.1161910, 2008.

Morin, S., Savarino, J., Frey, M. M., Dominé, F., Jacobi, H.-W., Kaleschke, L., and Martins, J. M. F., Comprehensive isotopic composition of atmospheric nitrate in the Atlantic Ocean boundary layer from $65^{\circ} \mathrm{S}$ to $79^{\circ} \mathrm{N}$, J. Geophys. Res., 114, D05303, doi:10.1029/2008JD010696, 2009.

Oltmans, S. J., Johnson, B. J., and Helmig, D.: Episodes of high surface-ozone amounts at South Pole during summer and their impact on the long-term surface-ozone variation, Atmos. Environ., 42, 2804-2816, 2008.

Oncley, S. P., Buhr, M., Lenschow, D. H., Davis, D., and Semmer, S. R.: Observations of summertime NO fluxes and boundarylayer height at the South Pole during ISCAT 2000 using scalar similarity, Atmos. Environ., 38, 5389-5398, 2004.

Press, W. H., Flannery, B. P., Teukolsky, S. A., and Vetterling, W. T.: Numerical Recipes in C: The Art of Scientific Computing (Second Edn.), Cambridge University Press, doi:10.2277/0521431085, 1993.

Qiu, R., Green, S. A., Honrath, R. E., Peterson, M. C., Lu, Y., and Dziobak, M.: Measurements of $\mathrm{JNO}_{3}^{-}$in snow by nitrate-based actinometry, Atmos. Environ., 36, 2563-2571, 2002.

Read, K. A., Mahajan, A. S., Carpenter, L. J., Evans, M. J., Faria, B. V. E., Heard, D. E., Hopkins, J. R., Lee, J. D., Moller, S. J., Lewis, A. C., Mendes, L., McQuaid, J. B., Oetjen, H., SaizLopez, A., Pilling, M. J., and Plane, J. M. C.: Extensive halogenmediated ozone destruction over the tropical Atlantic Ocean, Nature, 453, 1232-1235, doi:10.1038/nature07035, 2008.

Richter, A., Wittrock, F., Ladstaetter-Weissenmayer, A., and Burrows, J. P.: GOME measurements of stratospheric and tropospheric BrO, Adv. Space Res., 29, 1667-1672, 2002. 
Ridley, B., Walega, J., Montzka, D., Grahek, F., Atlas, E., Flocke, F., Stroud, V., Deary, J., Gallant, A., Boudries, H., Bottenheim, J., Anlauf, K., Worthy, D., Sumner, A. L., Splawn, B., and Shepson, P.: Is the Arctic Surface Layer a Source and Sink of $\mathrm{NO}_{\mathrm{x}}$ in Winter/Spring?, J. Atmos. Chem., 36, 1-22, 2000.

Ridley, B. A. and Orlando, J. J.: Active Nitrogen in Surface Ozone Depletion Events at Alert during Spring 1998, J. Atmos. Chem., 44, 1-22, 2003.

Ryerson, T. B., Williams, E. J., and Fehsenfeld, F. C.: An efficient photolysis system for fast-response $\mathrm{NO}_{2}$ measurements, J. Geophys. Res., 105, 26447-26461, 2000.

Salawitch, R. J., Canty, T., Kurosu, T., Chance, K., Liang, Q., da Silva, A., Pawson, S., Nielsen, J. E., Rodriguez, J. M., Bhartia, P. K., Liu, X., Huey, L. G., Liao, J., Stickel, R. E., Tanner, D. J., Dibb, J. E., Simpson, W. R., Donohoue, D., Weinheimer, A., Flocke, F., Knapp, D., Montzka, D., Neuman, J. A., Nowak, J. B., Ryerson, T. B., Oltmans, S., Blake, D. R., Atlas, E. L., Kinnison, D. E., Tilmes, S., Pan, L. L., Hendrick, F., Van Roozendael, M., Kreher, K., Johnston, P. V., Gao, R. S., Johnson, B., Bui, T. P., Chen, G., Pierce, R. B., Crawford, J. H., and Jacob, D. J.: A new interpretation of total column $\mathrm{BrO}$ during Arctic spring, Geophys. Res. Lett., 37, L21805, doi:10.1029/2010GL043798, 2010.

Sander, S. P., Finlayson-Pitts, B. J., Friedl, R. R., Golden, D. M., Huie, R. E., Keller-Rudek, H., Kolb, C. E., Kurylo, M. J., Molina, M. J., Moortgat, G. K., Orkin, V. L., Ravishankara, A. R., and Wine, P. H.: Chemical Kinetics and Photochemical Data for Use in Atmospheric Studies, Evaluation Number 15, JPL Publication 06-2, Jet Propulsion Laboratory, Pasadena, 2006.

Saiz-Lopez, A., Mahajan, A. S., Salmon, R. A., Bauguitte, S. J.B., Jones, A. E., Roscoe, H. K., and Plane, J. M. C.: Boundary layer halogens in coastal Antarctica, Science, 317, 348-351, doi:10.1126/science.1141408, 2007a.

Saiz-Lopez, A., Chance, K., Liu, X., Kurosu, T. P., and Sander, S. P.: First observations of iodine oxide from space, Geophys. Res. Let., 34, L12812, doi:10.1029/2007GL030111, 2007 b.

Saiz-Lopez, A., Plane, J. M. C., Mahajan, A. S., Anderson, P. S., Bauguitte, S. J.-B., Jones, A. E., Roscoe, H. K., Salmon, R. A., Bloss, W. J., Lee, J. D., and Heard, D. E.: On the vertical distribution of boundary layer halogens over coastal Antarctica: implications for $\mathrm{O}_{3}, \mathrm{HO}_{\mathrm{x}}, \mathrm{NO}_{\mathrm{x}}$ and the $\mathrm{Hg}$ lifetime, Atmos. Chem. Phys., 8, 887-900, doi:10.5194/acp-8-887-2008, 2008.

Schönhardt, A., Richter, A., Wittrock, F., Kirk, H., Oetjen, H., Roscoe, H. K., and Burrows, J. P.: Observations of iodine monoxide columns from satellite, Atmos. Chem. Phys., 8, 637653, doi:10.5194/acp-8-637-2008, 2008.
Seinfeld, J. H. and Pandis, S. N.: Atmospheric Chemistry and Physics: From Air Pollution to Climate Change, John Wiley \& Sons, Inc., 1998.

Simpson, W. R., von Glasow, R., Riedel, K., Anderson, P., Ariya, P., Bottenheim, J., Burrows, J., Carpenter, L. J., Frieß, U., Goodsite, M. E., Heard, D., Hutterli, M., Jacobi, H.-W., Kaleschke, L., Neff, B., Plane, J., Platt, U., Richter, A., Roscoe, H., Sander, R., Shepson, P., Sodeau, J., Steffen, A., Wagner, T., and Wolff, E.: Halogens and their role in polar boundary-layer ozone depletion, Atmos. Chem. Phys., 7, 4375-4418, doi:10.5194/acp-74375-2007, 2007.

Sjostedt, S. J., Huey, L. G., Tanner, D. J., Peischl, J., Chen, G., Dibb, J. E., Lefer, B., Hutterli, M. A., Beyersdorf, A. J., Blake, N. J., Blake, D. R., Sueper, D., Ryerson, T., Burkhart, J., and Stohl, A.: Observations of hydroxyl and the sum of peroxy radicals at Summit, Greenland during summer 2003, Atmos. Environ., 41, 5122-5137, 2007.

von Glasow, R., von Kuhlmann, R., Lawrence, M. G., Platt, U., and Crutzen, P. J.: Impact of reactive bromine chemistry in the troposphere, Atmos. Chem. Phys., 4, 2481-2497, doi:10.5194/acp4-2481-2004, 2004.

Weller, R., Jones, A. E., Wille, A., Jacobi, H.-W., McIntyre, H. P., Sturges, W. T., Huke, M., and Wagenbach D.: Seasonality of reactive nitrogen oxides $\left(\mathrm{NO}_{\mathrm{y}}\right)$ at Neumayer Station, Antarctica, J. Geophys. Res., 107, 4673, doi:10.1029/2002JD002495, 2002.

Wolff, E. W.: Nitrate in polar ice, in: Ice Core Studies of Global Biogeochemical Cycles, NATO ASI Ser., vol. 130, edited by: Delmas, R. J., Springer-Verlag, New York, 195-224, 1995.

Wolff, E. W., Jones, A. E., Martin, T. J., and Grenfell, T. C.: Modelling photochemical $\mathrm{NO}_{\mathrm{x}}$ production and nitrate loss in the upper snow pack of Antarctica, Geophys. Res. Lett., 29, 1944, doi:10.1029/2002GL015823, 2002.

Wolff, E. W., Jones, A. E., Bauguitte, S. J.-B., and Salmon, R. A.: The interpretation of spikes and trends in concentration of nitrate in polar ice cores, based on evidence from snow and atmospheric measurements, Atmos. Chem. Phys., 8, 5627-5634, doi:10.5194/acp-8-5627-2008, 2008.

Yang, X., Cox, R. A., Warwick, N. J., Pyle, J. A., Carver, G. D., O'Connor, F. M., and Savage, N.: Tropospheric bromine chemistry and its impact on ozone: A model study, J. Geophys. Res., 110, D23311, doi:10.1029/2005JD006244, 2005.

Zhou, X., Beine, H. J., Honrath, R. E., Fuentes, J. D., Simpson, W., Shepson, P. B., and Bottenheim, J.: Snowpack photochemical production as a source for HONO in the Arctic boundary layer in spring time, Geophys. Res. Lett., 28, 4087-4090, 2001. 